KULTURA - MEDIA - TEOLOGIA

ISSN 2081-89-71

$2021 \mathrm{nr} 44$, s. 99-131

\title{
Mateusz Flont
}

Uniwersytet Jagielloński w Krakowie

\section{Aksjologia audiowizualności (cz. 2). Rozważania teoretyków i praktyków podczas seminarium w Instytucie Dziennikarstwa, Mediów i Komunikacji Społecznej Uniwersytetu Jagiellońskiego (15.03.2019)}

Axiology of audiovisualness (part 2).

Considerations of theoreticians and practitioners during the seminar at the Institute of Journalism, Media and Social Communication Jagiellonian University (15/03/2019)

\begin{abstract}
ABSTRAKT
Poniższy tekst jest sprawozdaniem z seminarium naukowego, które odbyło się na Uniwersytecie Jagiellońskim. Poruszano na nim tematy wartości, które są przekazywane w mediach, filmach, literaturze, języku i szeroko pojętej sztuce. Oprócz przedstawienia referatów umieszczono również zapis dyskusji, które odbywały się między każdym wystąpieniem.

SŁOWA KLUCZOWE

wartości, audiowizualność, media, obraz rzeczywistości

ABSTRACT

The following text is a report from a scientific seminar that took place at the Jagiellonian University. It touched upon themes of values that are transmitted in the media, films, literature, language and broadly understood art. In addition to presenting the papers, there was also a presentation of discussions that took place between each speech.

\section{KEYWORDS}

values, audiovisualness, media, image of reality

\footnotetext{
Ceminarium naukowe „Aksjologia audiowizualności” odbyło się 15. marca 2019 Sroku w Instytucie Dziennikarstwa, Mediów i Komunikacji Społecznej w budynku Wydziału Zarządzania i Komunikacji Społecznej Uniwersytetu Jagiellońskiego w Krakowie.
} 
W pierwszej części sprawozdania zaprezentowano referaty profesorów Grzegorza Łęcickiego, Małgorzaty Lisowskiej-Magdziarz, Filipa Bajona i Michała Drożdża, a także dyskusje, które toczyły się między wszystkimi uczestnikami seminarium.

***

\section{Anna Gemra, „,Dobry potwór nie jest zły”. Manipulowanie obrazem zła w tekstach kultury popularnej}

Badając teksty kultury popularnej doszłam do wniosku, że to, co obserwujemy współcześnie, czyli, nazwę to ogólnie, relatywizacja zła, niekoniecznie jest signum temporis. Sądzę, że mamy do czynienia ze zjawiskiem od zawsze obecnym w kulturze, od zawsze z nią związanym. Tyle tylko że mniej lub bardziej się ukrywa podobne zabiegi, mniej lub bardziej sprytnie takimi obrazami się manipuluje. Swego czasu zajmowałam się wampirami (i dalej się nimi z upodobaniem zajmuję). $\mathrm{Na}$ podstawie obserwacji, jak przebiegała ewolucja tych postaci, mogę stwierdzić, że linia podziału między dobrem a złem, między potworem a nie-potworem, od któregoś momentu wyraźnie staje się nieostra.

Odwołam się tutaj do tekstów, które powstały jeszcze przed ekspansją tekstów kultury popularnej na rynki Europy w połowie XIX wieku. Już od końca XVIII wieku publikowano powszechnie tzw. powieści zbójeckie, które cieszyły się ogromną popularnością. Ich bohaterami byli, jak sama nazwa wskazuje, zbójcy, czyli przestępcy. Fabuła jednak była tak skonstruowana, że nie pokazywano ich jako postaci negatywnych, lecz pozytywnych: tych, którzy zabierali bogatym i oddawali biednym. Abelino, Ludwik Dominik Kartusz czy Rinaldo Rinaldini stali się ulubieńcami publiczności, zwłaszcza tej wywodzącej się z niższych sfer. Stali się symbolami walki z niesprawiedliwym systemem władzy.

Powieści zbójeckie podniosły do rangi postaci kultowych taki typ bohatera, który później nazwano „szlachetnym bandytą”. Samo w sobie pojęcie to, funkcjonujące także dziś, jest oksymoronem, natomiast mało kto w ten sposób o nim myśli. Obraz „szlachetnego bandyty”, dbającego o słabszych i kierującego się kodeksem rycerskim, utrwalił się tak silnie, że działacze oświatowi, usiłujący pokazać prawdziwe oblicze zbójców, byli z góry skazani na przegraną. Na nic zdawały się tłumaczenia, że na przykład Ludwik Dominik Kartusz, ale też i inni, to byli pospolici bandyci, złodzieje. Publiczność nie przyjmowała tego do wiadomości. Bardziej trafiał do niej przekaz, jaki wyłaniał się z powieści zbójeckiej. A głosił on mniej 
więcej tyle, że nie można oczekiwać sprawiedliwości od systemu. Mogą ją dać tylko ci, którzy są poza systemem, poza oficjalnym wymiarem sprawiedliwości: buntownicy, którzy wzięli sprawy we własne ręce.

W tej sytuacji bardzo ciekawe wydaje się zakończenie: zbójca, „szlachetny bandyta", zawsze ponosił karę. Nie miało znaczenia to, że jego postępki wynikały $\mathrm{z}$ wad systemu, a on sam działał w dobrej sprawie: ponieważ popełnił zbrodnię (przestępstwo), musiał ponieść karę. Wymierzano ją publicznie, gdyż czyny zbójcy też były dokonywane publiczne i stanowiły przekroczenie norm społecznych. Choć może to zaskakiwać, takiego finału oczekiwali również czytelnicy, ponieważ był on potwierdzeniem tego, że istnieją pewne zasady i nie wolno ich łamać. Współczesne realizacje wątku „szlachetnego bandyty” raczej nie mają takiego zakończenia, lecz happy end, co de facto jest pochwałą występku i krytyką systemu oraz obowiązujących zasad. Sprowadzić to można do stwierdzenia, że skoro system zawodzi, mamy prawo wystąpić przeciwko niemu, by zaspokoić swoje najważniejsze potrzeby, w tym potrzebę sprawiedliwości.

Innym przykładem takiego podejścia do postaci, których postępowanie nie mieściło się w granicach przyjętych norm, może być historia Gualezy, prostytutki z powieści Eugeniusza Sue Tajemnice Paryża. Choć bohaterka prostytuuje się nie $\mathrm{z}$ własnej woli i nawet $\mathrm{w}$ tym ciężkim położeniu nie przestaje być dobrym człowiekiem, musi ponieść karę. W zakończeniu powieści zatem, już uwolniona od swoich prześladowców, rozchorowuje się i umiera. Happy end jest niemożliwy: po tym, co robiła, Gualeza nie może już prowadzić normalnego życia, założyć rodziny. Podobnie dzieje się z Lucy, jedną z postaci Draculi Brama Stokera, powieści, która wyszła w 1897 roku. Wampiryzm Lucy nie jest jej winą: została zaatakowana przez Draculę. Skoro jednak stała się wampirzycą, musi umrzeć. Można było wampirowi (Lucy) współczuć, ale to nie oznaczało, że należało go akceptować. Zło musiało zostać usunięte: ktoś, kto przekracza normy społeczne, nie może żyć w społeczeństwie. Takie były zasady i powszechnie je akceptowano.

Wraz z upływem czasu wspomniane zasady zaczęły ulegać zmianie. Proces ten przyspieszył wraz z pojawieniem się filmu. Nie może to dziwić, ponieważ jest to medium bardziej agresywne. To, co zwizualizowane, wpływa na nas silniej niż tekst pisany, odwołuje się do tego, do czego od wieków jesteśmy przyzwyczajeni, tzn. do postrzegania świata nie poprzez słowa, ale obrazy. Za przykład posłużą mi tutaj trzy postaci z filmów wampirycznych, pochodzących z różnych okresów. 
Pierwsza z nich, hrabia Orlok, jest wampirem, bohaterem filmu Nosferatu symfonia grozy z 1922 roku, w reżyserii Friedricha Murnaua. Nie jest podobny do Draculi ze wspomnianej wcześniej powieści Stokera. Stokerowski bohater, choć też jest potworem i śmierdzi, o czym mówi narrator, nie jest aż tak przerażająco brzydki, aż tak odrażający. Potworności Draculi trzeba się domyślać, natomiast potworność - odmienność - hrabiego Orloka jest od początku oczywista.

Niecałe dziesięć lat po filmie Murnaua, w 1931 roku, pojawił się najsłynniejszy chyba wampir filmowy: Dracula grany przez Belę Lugosiego w filmie Toda Browninga, opartym teoretycznie na powieści Stokera. W rzeczywistości scenariusz nie miał wiele wspólnego z książką irlandzkiego pisarza, a wampir Browninga w ogóle nie jest podobny ani do Draculi Stokera, ani do Orloka Murnaua. Ubiera się, zachowuje i wygląda jak każdy inny mężczyzna z „towarzystwa”. Jego potworność, odmienność zostały dobrze ukryte. W ciągu niecałych dziesięciu lat dokonała się więc ogromna zmiana w wizerunku wampira.

Trzecia postać to wampir współczesny, bohater powieści i filmu sprzed ponad dziesięciu lat, mianowicie Edward ze Zmierzchu Stephenie Meyer. Pierwszy tom cykl ukazał się w 2005 roku, a pierwsza część trylogii filmowej weszła na ekrany w 2008 roku. Mamy tu do czynienia z ciekawą sytuacją. Edward jest wampirem, a więc potworem, odmieńcem, co jest widoczne w jego zachowaniu. Jednocześnie jednak pełni on funkcję szlachetnego wybawcy (na przykład ratuje Bellę przed potrąceniem przez auto); jest też przystojny, inteligentny, empatyczny, nawet potrafi narażać dla innych swoje życie. Słowem, to wampir, w którym można się zakochać (zresztą on sam też może się zakochać). Jego wampiryzm nie stanowi problemu: to po prostu kwestia ograniczeń dietetycznych, a tych nie wolno nam krytykować, jeśli chcemy być uznawani za ludzi nowoczesnych, cywilizowanych. Na dodatek on i jego rodzina to wegetarianie, jak mówią sami o sobie: nie piją ludzkiej krwi. To kolejny element, który ma wykluczyć Edwarda z grona przerażających potworów. Jakoś jednak umyka w interpretacji, że w takim ujęciu wegetarianizmu zwierzęta są roślinami, a ludzie zwierzętami...

Można tu także wspomnieć zrealizowany na podstawie powieści Lisy Jane Smith serial Pamiętniki wampirów, emitowany od 2009 do 2017 roku. Wampiry pokazane są w nim jako istoty prowadzące normalne życie, a picie krwi jest częścią tego życia: dieta jak każda inna.

Odwołam się tutaj także do powieści, która nie doczekała się ekranizacji, ale jest dobitnym dowodem na przemiany, jakie zaszły w obrazie wampiryzmu. 
Chodzi o Hotel Transylwania Chelsea Quinn Yarbro z 1978 roku. Główny bohater, hrabia Sain-Germain, pokazany jest jako istota o wiele lepsza od ludzi. Jest przystojny, empatyczny, dobrze wychowany. Jeśli chodzi o picie krwi, to potrzebuje jedynie jej odrobiny. Przychodzi we śnie i zostawia po sobie miłe wrażenia: jego ataki nie są przykre dla ofiar, a on sam robi to tylko po to, by przeżyć i stara się „zminimalizować szkody”. Ludzie natomiast atakują innych ludzi zupełnie bez powodu: nie muszą się odżywiać krwią, ale sprawia im przyjemność zadawanie bólu, patrzenie na cierpienie innych. Okazuje się więc, że współczesny wampir może być bardziej ludzki od ludzi. Może się stać, jak później Edward, idolem nastolatek, które dla niego zrezygnują z normalnego życia, przedstawicielem jeszcze jednego inteligentnego gatunku zamieszkującego Ziemię..

Warto też wspomnieć o innym typie postaci, niezwykle dziś popularnym czyli o superbohaterach. Upraszczając, można powiedzieć, że są to bohaterowie, którzy wprawdzie zabijają, ale w dobrym celu.. Spider-Man, Superman i wielu innych, cała grupa superbohaterów fantastycznych, często hybryd, którzy narodzili się w latach 30. XX wieku i później, ma jedno zadanie: uratować ludzkość.. Stoją ponad prawem i działają poza prawem, a publiczność to akceptuje, ponieważ - przynajmniej teoretycznie - działają w imię wyższych celów. To usprawiedliwia wszystkie ich czyny, w tym demontaż jednego najważniejszych osiągnięć cywilizacji: norm społecznych i systemu prawnego. Ale mamy też innych superbohaterów, niekoniecznie fantastycznych. Klasycznym przykładem jest agent 007 - James Bond, z licencją na zabijanie, przyznaną przez rząd. Kiedy bohater zaczyna działać, okazuje się, że organy śledcze, prokuratura, sąd są zbyteczne, ponieważ agent 007 pełni ich role. To on ustala, kto popełnił przestępstwo, wydaje wyrok i go wykonuje. Trzeba podkreślić przy tej okazji jedną rzecz: wszyscy ci bohaterowie prowadzą bardzo ekscytujące życie, pełne fascynujących przygód. W rezultacie do przeciętnego odbiorcy dociera przekaz, że „zwykła” egzystencja jest po prostu nudna. Doskonale to widać w filmie Brada Birda Iniemamocni z 2004 roku, który mogą oglądać również dzieci pod kontrolą rodziców. Kiedy pan Iniemamocny zostaje zwolniony z funkcji superbohatera, musi prowadzić takie życie, jak inni ludzie: chodzić do pracy, zajmować się rodziną itd. Codzienność okazuje się uciążliwie monotonna, a praca - ogłupiająca. Może to wynikać z tego, że protagonista nie jest zwykłym człowiekiem, ma więc silniejszą chęć bycia potrzebnym. Nie zmienia to jednak faktu, że to, co jest normalne, zostało w filmie sprowadzone do nudy, co uwidacznia się także w sposobach pokazywania Iniemamocnego w „zwykłej” $\mathrm{i}$ „superbohaterskiej” pracy. 
Ostatnią kwestią, o której opowiem, jest sprawa Minionków, bohaterów kilku filmów kinowych przeznaczonych dla dzieci, z których pierwszy, Jak ukraść Księżyc, ukazał się w 2010 roku. Minionki to budzący uśmiech psotnicy: publiczność bawi to, co robią, ich wygląd, zachowanie. Trudno uznać je za bohaterów negatywnych. Chciałabym jednak zwrócić uwagę na film Minionki wypuszczony w 2015 roku i będący prequelem do Jak ukraść Księżyc. Opowiada on historię Minionków. Okazało się, że od początku swego istnienia szukają one mistrza. A ponieważ postanowiły się poświęcić złu, szukają kogoś, kto będzie mistrzem zła. Akcja jest tak poprowadzona, że każdy szef, którego znajdą sobie Minionki, ostatecznie przed nimi ucieka i ginie. Odbiorcy naiwnemu łatwo więc o wniosek, że można robić złe rzeczy, ponieważ ostatecznie i tak wszystko dobrze się skończy; nie będzie żadnych negatywnych konsekwencji zła, które uczyniliśmy.

W omówionych wcześniej produkcjach na plan pierwszy wysuwa się kilka spraw. Po pierwsze, często przemoc ukazywana jest jako lek na całe zło. Pod pozorem służenia dobru i ludzkości propaguje się rozwiązania siłowe: to one zwyciężają, a nie rozwiązania „rozumowe”, pokojowe. Przemoc jest też pokazywana w taki sposób, jakby jej w ogóle nie było, jakby nic się nie stało. Po drugie, nie-ludzkie jest ukazywane jako lepsze niż ludzkie: nie-ludzie są silniejsi, sprytniejsi, mądrzejsi, często też bardziej empatyczni niż my. Jeśli jesteśmy osobami cywilizowanymi i tolerancyjnymi musimy przyjąć do wiadomości fakt, że potwory, tak jak w Hotelu Transylwania, bajce Genndy Tartarkovsky'ego z 2012 roku, są dobre, a ludzie źli. To oni przeszkadzają superbohaterom i potworom w naprawianiu świata. Co więcej, każde zło ma swoje logiczne, akceptowalne wytłumaczenie i każde zło może się skończyć dobrze, jak w historii Minionków.

Wszystkie te kwestie nie są bez znaczenia, jeśli się pamięta, że po drugiej stronie ekranu (ale i książki czy gry) mamy bardzo często tak zwanego odbiorcę naiwnego. To odbiorca, który, w pewnym sensie, utożsamia fikcję z rzeczywistością, a przynajmniej nie dość wyraźnie je od siebie oddziela. Oglądając film lub czytając książkę przyjmuje fikcję tak, jakby była to rzeczywistość. Zaznaczę od razu, że kategoria odbiorcy naiwnego nie dotyczy wyłącznie dzieci; nie ma też nic wspólnego z wykształceniem. Chodzi o tę część publiczności, która, oglądając na przykład film o Jamesie Bondzie, będzie uważała, że obraz ten jest/może być odzwierciedleniem przygód, jakie mają agenci wywiadu; o tę grupę odbiorców, dla której film o czarodziejach będzie stanowił propagowanie okultyzmu, a horror ujawniał stan umysłu i osobiste poglądy scenarzysty i reżysera. Wydawać się 
może, że ten typ odbiorcy należy do przeszłości, bo przecież istnieje obowiązek szkolny, a szkoła daje narzędzia do świadomej recepcji tekstu kultury, uczy różnicy pomiędzy światem fabularnym a światem rzeczywistym. Nic bardziej mylnego: kategoria odbiorcy naiwnego, charakterystyczna na przykład dla XIX wieku, nie tylko nie zniknęła, ale ma się świetnie, na co istnieją liczne dowody.

Wiążą się z tym określone problemy. Otóż jako (potencjalni) twórcy filmu dokumentalnego powinniśmy się trzymać faktów. Zwykle też są one, przynajmniej do jakiegoś stopnia, znane odbiorcy, zatem trudniej nimi manipulować, choć oczywiście możemy je przedstawiać w taki sposób, by zasugerować publiczności interpretację. Natomiast w wypadku filmu fabularnego sytuacja jest łatwiejsza: można tak ukształtować fabułę, żeby zmanipulowała odbiorcę i zmieniła jego sposób postrzegania dobra i zła, a on nawet nie będzie o tym wiedział.

\section{Dyskusja po referacie prof. Anny Gemry}

Małgorzata Lisowska-Magdziarz: Uwielbiam te dyskusje, gdy zdradzamy swoje upodobania popkulturowe. Wszystko, co możemy powiedzieć o kulturze popularnej, zawsze w obszarze pewnego zestawu założeń okazuje się prawdziwe. Dlatego dyskutuję tutaj bardziej dla przyjemności wymiany myśli, niż dla udowodnienia czegokolwiek. Ponieważ jednak od kilku lat nic innego właściwie nie czytam, tylko fanfiction, to jestem - w oparciu o empiryczny ogląd - przekonana, że odbiór naiwny, być może gdzieś tam istnieje w jakimś obszarze, ale chyba w o wiele mniejszym, niż się wydaje... W twórczości oddolnej widać, że zdolność ludzi do renegocjowania aksjologii jest niesłychanie wyrafinowana i wysoka w porównaniu do tego, co by nam się czasem wydawało. Zresztą, jeśli się przyjrzeć na przykład narracjom o superbohaterach, to cały Marvel to są przecież toposy zaczerpnięte $\mathrm{z}$ antyku czy od Szekspira. Ostatnim filmem tego etapu rozwoju uniwersum narracyjnego MCU serii jest Koniec gry, idący w stronę wielkiego aksjologicznego rozwiązania po stronie dobra.

Anna Gemra: Za pomocą zła...

Małgorzata Lisowska-Magdziarz: No nie, niekoniecznie za pomocą zła. Tego jeszcze nie wiemy, to właśnie zobaczymy. Natomiast mnie bardziej niepokoi Jim Jarmusch i niesłuchanie atrakcyjny, trujący urok nihilizmu w filmie Tylko kochankowie przeżyja, w którym nikt nie udaje, że wampiry są figurą wyrzuconych poza nawias. Nikt nie próbuje udawać, że one są oceniane negatywnie czy że w ogóle jakaś aksjologia tu istnieje. One są bytem naturalnym, że tak powiem, 
do tego jeszcze wiekuistym. Mnie się to wydaje z aksjologicznego punktu bardziej niepokojące niż te sytuacje, w których te Minionki jak szatan „wiecznie zła pragnąc, wiecznie czynią dobro".

Filip Bajon: No, ale Jarmusch... Mnie się w świecie tej refleksji naukowej podoba, że nie ma stopniowania gatunków.

Małgorzata Lisowska-Magdziarz: Jeżeli mówię o Jarmuschu, to jako ktoś, kto siedzi w badaniach nad fandomem, czyta twórczość oddolną - nastolatków czy gospodyń domowych w średnim wieku, czyli odbiorców, których bardzo stereotypowo uważa się za odbiorców naiwnych. Otóż Tylko kochankowie... to film artystyczny, który został przeniesiony do sfery kultury popularnej. Nie funkcjonuje jako tekst wysoki, tylko jako produkt popkultury. Jest odbierany jako trochę guilty pleasure, trochę ukochana bajka, którą się ogląda wciąż od nowa, trochę podstawa pod fantazje erotyczne. W internecie w związku z tym są setki memów z nagimi Tomem Hiddlestonem i Tildą Swinton; jest fanfiction wyrażająca fascynację ich miłością; jest zafiksowanie fanów na szczegółach - na przykład że oni muszą nosić rękawiczki, żeby słońce im nie zrobiło krzywdy, albo jedzą lodowe lizaki z krwi. Mordercze wampiry są absolutnie czarujące i urocze. I to jest absolutnie nihilistyczne.

Anna Gemra: Ale absolutnie czarujący i uroczy są też Bella i Edward. To akurat jest przekaz skierowany do nastolatków, jednak mówiąc o odbiorcy naiwnym, nie myślałam o żadnej konkretnej grupie społecznej, wiekowej itd.

Małgorzata Lisowska-Magdziarz: ....ale tam jest aksjologia. Jest miłość, która wygrywa. Jest ten wampir, który z miłości ogranicza swe mordercze instynkty, a także popęd seksualny. To jest przesłanie dla nastolatek, że należy poczekać. On ją tak niewinnie kocha, bardzo długo...

Anna Gemra: Pozwolę się z tym nie zgodzić, dlatego że nie uznaję za niewinną miłości, w której jedna osoba, nawet zakochana, podgląda drugą, na dodatek w warunkach intymnych, domowych. A takie sytuacje się w Zmierzchu zdarzają. Nie uważam też za niewinną miłości, w której jedna osoba, myślę o Edwardzie, ma tak wielką przewagę psychiczną nad drugą, jaką ma on nad Bellą (i zresztą także nad innymi ludźmi). Może na nią wpływać właściwie w dowolny sposób, ona zaś jest bezradna wobec takiej przemocy psychicznej, nawet jej nieświadoma. Tyle zatem w kwestii mojej opinii na temat niewinności tego uczucia.

Chciałam się też odnieść do kategorii odbioru naiwnego, w pewnym sensie się usprawiedliwić. Powtórzę: nie wiążę go z żadną konkretną grupą społeczną, 
ponieważ sądzę, że z odbiorem naiwnym mamy do czynienia dość powszechnie i że ten typ odbioru reprezentuje duża część społeczeństwa. Czuje się ona przygotowana do odbioru tekstów kultury, ale jest to jedynie teoria. W praktyce publiczność taka jest w stanie „odczytywać” teksty jedynie na poziomie podstawowym, niepogłębionym. Często też nadpisuje na nich znaczenia, których w nich nie ma. Taka sytuacja była chociażby z cyklem o Harrym Potterze, interpretowanym na różne sposoby, także silnie zideologizowane. Można by zapytać autorki - to podobno jest „klasyczne” pytanie filologów - co miała na myśli, pisząc opowieść o dorastaniu czarodzieja? Jaki cel przyświecał jej przy tworzeniu fabuły? Takie pytanie nie padło, nie znamy więc odpowiedzi: odbiorcy jednak dodają własne znaczenia.

Małgorzata Lisowska-Magdziarz: Ale zdolność do negocjacji i nadpisywania znaczeń raczej wskazywałaby na aktywny stosunek do tekstu kultury niż na bierny.

Anna Gemra: Odbiór naiwny nie jest odbiorem biernym, przeciwnie - to odbiór bardzo aktywny. Tyle tylko że takiemu odbiorcy wydaje się, iż ma kompetencje do odbioru tekstu i nadaje mu własne znaczenia.

Małgorzata Lisowska-Magdziarz: To jego prawo.

Anna Gemra: Zgadza się. To jest prawo odbiorcy: twórca oddaje mu tekst, a on interpretuje go po swojemu. Natomiast pozostaje pytanie o to, co rzeczywiście w tekście jest. 0 problemie tym swego czasu mówił Piotr Kowalski: otóż jeśli punktem oparcia dla interpretacji powinien być tekst kultury, to należy zapytać o to, co jest w utworze, a co na ten utwór nakłada odbiór, w tym odbiór naiwny. Jeśli interpretacja nie opiera się o tekst, to efekty mogą być takie, jak po książkach i filmach o przygodach Harry'ego Pottera. Z jednej strony oskarżano je między innymi o propagowanie okultyzmu, co sprawiło, że część publiczności mocno zdystansowała się od tego cyklu, często nawet nie mając za sobą jego lektury. Z drugiej - narodził się fandom. Dla wielu jego uczestników Harry Potter jest postacią „rzeczywistą”. Podobne zachowania widać na przykład w działalności niektórych grup rekonstrukcyjnych, odtwarzających fikcyjne wydarzenia z tekstów kultury. W wyniku doświadczeń lekturowych tworzą się też kulty, jak na przykład kult wampiryzmu: początek wampirycznym domom dała przecież w dużej mierze gra Wampir: Maskarada z 1991 roku. 


\section{Jarosław Gugała „Mowa nienawiści we współczesnych mediach elektronicznych"}

Ja mam mówić o mowie nienawiści, ale okazuje się, że temat jest trudny choćby z tego powodu, że my nie wiemy, co to jest. Są próby zdefiniowania mowy nienawiści, ale zjawisko jest na tyle szerokie, że wymyka się i nadmiernie precyzyjnym, i zbyt ogólnym definicjom.

Ogólnie, intuicyjnie, przyjmuje się, że jest to zjawisko, polegające na używaniu języka w celu rozbudzenia nienawiści, niechęci albo usprawiedliwieni dyskryminacji i agresji, wobec osób, które są przedstawiane z jakiegoś powodu jako cel naszych działań. Mowę nienawiści na pewno można zdefiniować jako coś co doprowadza czy może doprowadzić do przestępstw wynikających z nienawiści, do utrwalania pewnych stereotypów itd. Z mową nienawiści jest tak, że my ją $\mathrm{w}$ tej chwili widzimy prawie wszędzie. Jest jej dużo w mediach, $\mathrm{w}$ radiu i telewizji, jeszcze więcej w Internecie i to się potem przenosi na ulicę. Widzimy ją na murach, w różnych miejscach, gdzie jest echo tego, co ludzie usłyszeli i zobaczyli. No, i w bezpośrednim otoczeniu w rozmowach z innymi ludźmi. Dlaczego mowa nienawiści istnieje, chociaż sama nazwa jest taka, że możemy to uznać, za rzecz kompletnie niepożądaną? Mówiliśmy już o kategorii nudy, a ona (mową nienawiści) nie jest nudna. Chętnie się nią posługujemy, żeby nudę rozwiać. Dwa - ona jest emocjonalna, w związku z powyższym pozwala łatwo docierać w zasadzie do każdego człowieka, ponieważ emocje docierają prawie do każdego człowieka. Więc charakteryzuje się masowością, a współczesne media to masowość. W zasadzie nikt nie rozwija żadnego medium ani żadnego komunikatora po to, żeby zawężać liczbę odbiorców - wręcz przeciwnie, powszechnym pragnieniem jest posiadanie wpływów na miliony.

Mowa nienawiści oparta na emocjach jest rzeczą bardzo użyteczną i powszechnie stosowaną w mediach. Najczęstsze ofiary mowy nienawiści to młodzi Polacy w wieku 16-18 lat (to są badania Fundacji Batorego sprzed 2 lat, mogły się zmienić, ale nie sądzę, żeby aż tak bardzo): mniejszości nieheteronormatywne, mniejszość romska, murzyni (czyli osoby o innym kolorze skóry), czy Żydzi. O dziwo na tym samym poziomie jest w Polsce niechęć do muzułmanów. To się powinno wykluczać, bo gdy nienawidzimy Żydów, to powinniśmy lubić muzułmanów i odwrotnie. Na końcu mniejszość ukraińska. Jeśli chodzi o to, gdzie ludzie spotykają najwięcej: homofobiczna mowa nienawiści to jej 77\%, rasizm 70\%, antyromizm 66\%, antysemityzm 59\%, antymuzułmańskość 55\% i antyukraińskość 46\%. 
To tyle teorii. Jak to się przekłada na praktykę? Bo ja jestem praktykiem i mam swoje przemyślenia na temat mediów, które są sprawcą bardzo wielu nieszczęść, ale również po prostu wykorzystują pewne zjawiska istniejące, pewne cechy ludzkości, dla swoich własnych interesów, dlatego żeby po prostu istnieć. Moim zdaniem mowa nienawiści istnieje, dlatego że chce jej bardzo duża część populacji. Ludzie chcą mowy nienawiści, ponieważ ona im odpowiada z różnych powodów, np. jest antidotum na nudę. Dwa - jest łatwa. Internet np. gwarantuje kompletną bezkarność. Ludzie się wyżywają w mowie nienawiści, bo są anonimowi. Rzeczy, które piszą w Internecie, nie powiedzieliby na głos. U nas kiedyś w redakcji była afera, bo prominentny dziennikarz, znany bardzo i często moralizatorsko się wypowiadający, zostawił otwarty komputer, nie zamknął stron, na których był, a gdzie „obrabia pewne części ciała” swoim kolegom i rodzinie. Nikt by go nie podejrzewał o coś takiego, a to było czarno na białym. Kiedy mógł mieć anonimowość, to z niej po prostu skorzystał. W związku z powyższym, mowa nienawiści jest atrakcją.

Zwróćcie uwagę na to, co się dzieje w mediach, na pewne okrucieństwa. Np. człowiek ma potrzebę, żeby przyglądać się poniżeniu innych ludzi. To jest wykorzystywane od dłuższego czasu, od momentu pojawienia się formatu Big Brother. To jest powszechnie wykorzystywane w innych formatach. Nawet w programach kulinarnych mamy taką sytuację, że stoi kilku nieszczęśników, każdy z nich jest mistrzem w gotowaniu, ale dziś jeden musi odpaść. Jest ten suspens i wszyscy czekamy na kogo wskażą sędziowie. To jest powszechne, podobnie w „Tańcu z gwiazdami”, to jest klasyczny przykład mowy nienawiści. To jest klasyczny przykład tego, że szerokim odbiorcom odpowiada rola świadków czyjegoś poniżenia. To się przejawia w tym, jeśli chodzi o publicystykę i informację, że jeśli ktoś kogoś pokona w jakiejś potyczce słownej, to potem można go dobić wpisując w Internecie swoje komentarze. Następuje „dyktatura masowego", prymitywnego - pani mówi „naiwnego” - widza, który łaknie przemocy, poniżania innych. Okazuje się, że tego widza jest bardzo dużo, bo te programy mają bardzo dużą oglądalność. Więc musi być w tym jakaś przyjemność. Człowiek musi ją mieć, jeśli na co dzień będzie oglądał coś, w czym widzi poniżenie innych ludzi. Normalną reakcją przyzwoitego człowieka powinna być niechęć do tego rodzaju widowisk. Ale już od czasów rzymskich wiemy, że tłum skazywał. Uwielbiał decydować, czy zabić kogoś, czy nie. A ktoś miał tę władzę i wszyscy się tym podniecali. To cały czas istnieje i to w mediach widać bardzo wyraźnie. 
Dziennikarstwo ma kodeksy etyczne, wiele dziś mówiliśmy o etyce. One bardzo często są kopiami kodeksów, które się sprawdziły. Natomiast u nas one są praktycznie nieużywane, tzn. one są zawieszone w dzisiejszych czasach z dwóch powodów: po pierwsze, że się rozpanoszyły media tożsamościowe - czyli takie media, które abdykowały ze swojej roli objaśniania świata i są po prostu instrumentem propagandy partyjnej, politycznej. Ich dziennikarze nie uprawiają dziennikarstwa po to, żeby dochodzić prawdy, tylko uprawiają je po to, żeby jacyś ludzie, których oni wspierają, wygrali wybory, bo oni się potem im odpłacą, dając im koncesje, dotacje, ogłoszenia państwowych spółek i rządu - i głównie po to jest uprawiane tego rodzaju dziennikarstwo. Zaniknęła podstawowa funkcja dziennikarstwa, jaką powinno być studiowanie rzeczywistości i przedstawianie odbiorcom racjonalnych wniosków ze studiowania rzeczywistości. To w ogóle prawie $\mathrm{w}$ tej chwili nie istnieje; tzn. istnieje, ale jest tak bardzo rozproszone, że dominuje wrażenie aksjologicznej pustki. To z kolei powoduje, że media nie tylko abdykują z wyjaśniania świata, ale też z jakiejkolwiek trudniejszej formy.

Masowość jest wymagana od mediów elektronicznych, bo tylko na masowości można zarobić. Nie ma takiego mechanizmu, że my mamy społeczeństwo obywatelskie, grupę świadomych obywateli, którzy chętnie się złożą i zapłacą grupie wybitnych dziennikarzy za to, żeby oni dla nich opisywali świat, badali pewne zjawiska, żeby potem ta publiczność mogła podejmować jakieś racjonalne wnioski, dotyczące ich życia, biznesu czy czegoś u nas w ogóle... Gazety próbują sprzedawać prenumeraty wersji papierowych i dostęp do swoich stron internetowych, ale ludzi, którzy są gotowi płacić dziennikarzom za dobrą, ciężką robotę jest u nas zdecydowanie za mało. Media rezygnują przez to także z trudniejszych form. Na przykład w pewnym momencie zaczął zanikać reportaż. Dopiero gdy udało się wypromować modę na tę formę na niektórych można było zacząć coś zarabiać. Zwróćcie uwagę na polskie programy publicystyczne. One niczego już nie wyjaśniają, ponieważ rezygnuje się z form przedstawienia prawdy, analizowania pewnej rzeczywistości, pewnych danych. Publicystyka polega teraz wyłącznie na sadzaniu na przeciwko siebie ekstremistów i szczuciu ich na siebie. Ponieważ mowa nienawiści się lepiej sprzedaje. Ludzie, którzy na siebie warczą, mają skrajne poglądy i są niekompatybilni, gwarantują powodzenie programu i jego dużą oglądalność. Program, który spokojnie, dogłębnie, próbuje coś wyjaśnić, odwoływać się nie do emocji, nie do naiwności - nie ma większych szans. tzn. w mediach elektronicznych. Tak w każdym razie się wydaje tym, którzy decydują w tym świecie. 
Komercjalizacja wywołuje fatalne zjawiska. Zanika to, co nazywam backgroundową pamięcią mediów. Dzisiaj można sprzedać każdą lipę, dotyczącą rzeczy, które niedawno jeszcze były znane, ponieważ ludzie tego nie pamiętają i nie pamiętają tego też dziennikarze, którzy tworzą dzisiejsze media. Więc jeżeli dziennikarz nie kojarzy czegoś, co było 10, 15, 20 lat temu, już nie mówiąc o tym, co było 70, i nie ma backgroundu intelektualnego odpowiedniego, to on za każdym razem wywala otwarte drzwi, zaczyna tę samą gadkę. I co parę lat można eksploatować dawno już wyjaśnione aspekty rzeczywistości i tematy, ponieważ publiczność jest naiwna i w większości nie kojarzy tego, że ktoś jej sprzedaje odgrzewaną potrawę. Dzięki temu media mogą po wielokroć komercjalizować stare sensacje. Większość odbiorców tego po prostu nie rozumie.

Rozrastają się tak zwane media tożsamościowe oferujące odbiorcom o silnych przekonaniach politycznych wersje wydarzeń potwierdzająca ich światopogląd. Często zdarzają mi się przypadki, że ktoś się do mnie odzywa po jakimś programie i mówi: „Ale pan jest mądry, pan myśli dokładni to samo co ja!”. To jest śmieszne, to jest absurdalne. Ludzie tak myślą i są bardzo rozczarowani, kiedy ja na to reaguje: „Bardzo przepraszam, ale to, że pan myśli, to samo, co ja, to nie znaczy, że my obaj jesteśmy mądrzy. Bo możemy się obaj mylić". Na coś takiego nikt nie jest w tej chwili w Polsce przygotowany. Każdy szuka jednak tej tożsamości, potwierdzenia swej własnej mądrości. Mało tego, ludzie nie uważają za wartość tego, że można wejść do dyskusji z jakimś poglądem, a wyjść z innym, bo ktoś nas może przekonać, bo można się dowiedzieć czegoś, o czym nie mamy zielonego pojęcia. Nie chcemy nowości oraz inności. Nasz społeczny i polityczny fantazmat jest tak silny i tak ugruntowany, że wszystko, co do niego nie pasuje, jest po prostu odrzucane.

Co mogłoby stanowić antidotum? Tzw. media publiczne byłyby antidotum, gdybyśmy się dogadali jako społeczeństwo, że my musimy mieć media, które razem wszyscy zgodnie finansujemy po to, żeby one maksymalizowały pewne wartości, które w inny sposób są zagrożone - piękną polszczyznę, tożsamość kulturową, artystyczną; które próbowałyby rzadsze i nie spotykające się z zainteresowaniem masowej publiczności, zjawiska artystyczne, które promowałyby prawdziwe wartościowe postawy, a nie tylko oferowały seksualne transfery tzw. celebrytów i pompowały ludziom do głowy, że jedyną drogą do osiągnięcia szczęścia jest tzw. gwiazdorstwo. Co jest w tej chwili jakąś totalną aberracją, paranoją. 
Ostatnio zajrzałem do internetu do jednego z popularnych portali, które wyglądają, jakby nie było w nich już redakcji, tylko tzw. algorytmy. One są skomplikowane i polegają na tym, co może liczyć na największe zainteresowanie. I nagłówek był taki: „Tęskniliście za konfliktem wśród celebrytek? Znowu jest! Pani X skrytykowała sukienkę kogoś tam". Ja nie wiem, kto to jest pani X, na sukienkach się nie znam, więc mnie to nie kręci. Zaglądam tam, a tam są dwa miliony wejść! Czyli okazuje się, że to działa. Teraz następna rzecz z tego wynikająca - ta X jest interesująca dlatego, że się pokłóciła z inna jakąś, nie dlatego, że zrobiła coś dobrego dla ludzkości. Kompletnie nie jest to istotne. Ona się pokłóciła. I nam wskazują, wejdź tam, zobaczysz, jak one się kłócą. To jest kolejny przykład promocji mowy nienawiści w szerokim rozumieniu tego słowa.

Ponieważ nie ma mediów publicznych, a media zawłaszczone są mediami tożsamościowymi, nie chronią żadnych wartości. Mają do spełnienia ważniejszą z punktu widzenia swoich mocodawców funkcję promowania postaw politycznych. Winę za to ponosi również chory system w Polsce dystrybucji środków publicznych na media. My mamy to w konstytucji zapisane, że obowiązkiem każdej władzy jest promowanie jak najbardziej spluralizowanej palety poglądów i środków wyrazu. Czy którakolwiek władza spełniała ten postulat wpisany w konstytucji? Stopień politycznego zawłaszczenia mediów publicznych osiąga szczyty. GW, Rzepa i inne ważne gazety w Polsce, które mają dużo odbiorców nie dostają ani grosza, ani jednego ogłoszenia państwowego i dzieje się to za przyzwoleniem całego polskiego społeczeństwa. Nikt w tej sprawie nie protestuje. A przecież te media stanowią coś więcej niż tylko siedlisko politykierów, opcji, którą zwalcza aktualna władza. One są też nośnikiem pewnych wartości, które może warto by było wspierać. KRRiT nie przekazuje żadnych pieniędzy mediom komercyjnym na produkcję programów wartościowych, np. dokumentów, reportaży, wywiadów, dokumentowanie wybitnych postaci, które żyją, a którymi się obecnie pies z kulawą nogą nie interesuje, ponieważ nie są celebrytami. No i my obywatele się na to zgadzamy. Taka postać, żeby zaistnieć, żeby mogła być słuchana, musi zaistnieć w kontekście mowy nienawiści. Albo musi sama kogoś zaatakować, albo sama musi zostać zaatakowana. Taka jest logika tego wszystkiego. Ponieważ emocje są łatwiejsze niż wartości intelektualne.

$\mathrm{Na}$ świecie ten problem istnieje wszędzie, natomiast on istnieje w mniejszym stopniu tam, gdzie znajduje się więcej ludzi, którzy chcą się temu przeciwstawiać i domagają się środków, nakładów na ochronę wartości. Tak jak pani 
profesor mówi, że czekacie na środki na badanie, które powie nam prawdę o polskim społeczeństwie w sensie tego, jakie my obrazy mamy w głowach. Na coś takiego to powinni stać w kolejce do was, ci, którzy dysponują pieniędzmi. Natomiast nie wiem, czy będą stali w kolejce, bo nie dowiedzą się tego z mediów. Żadne medium do pani nie przyjdzie, pani profesor, nie nagłośni tego w żadnym programie, że taki projekt w ogóle powstaje. Może będzie miała pani szczęście i przez swoje układy wejdzie pani do jakiegoś medium elektronicznego albo powie gdzieś tam w internecie, ale czy to będzie miało wielki odzew? Obawiam się, że nie. Dlatego że algorytm wyrzuci panią gdzieś daleko, a na pierwszą stronę wyrzuci parę tematów nacechowanych mową nienawiści. Więc żeby to nagłośnić, musiałaby pani wejść jakoś w tę mowę nienawiści i np. powiedzieć, że chcecie zbadać, dlaczego Polacy są takimi draniami. Albo dlaczego tak wszyscy kłamią. I wtedy powstanie skandal, powiedzą, że na UJ zalęgła się jakaś klika, która chce wykorzystywać tę szacowną instytucję, do szerzenia jakiejś zgnilizny moralnej, ale to zagwarantuje istnienie $\mathrm{w}$ dzisiejszych mediach. Innej drogi na razie nie widać.

Proszę zwrócić uwagę jeszcze na jedną rzecz. Ja pracuję w programach informacyjnych. Kiedy zaczynałem pracę, to był początek lat 90., pracowałem wtedy w redakcji zagranicznej, w weekendy cały dziennik był poświęcony tematyce międzynarodowej, ponieważ w kraju się zwykle nic nie działo. Więc robiliśmy prawie 30 minut informacji ze świata. A co się dzieje dzisiaj? Jeśli się pojawia jakakolwiek informacja z zagranicy $\mathrm{w}$ jakimś polskim dzienniku, to tylko $\mathrm{w}$ kontekście albo sensacji, albo są jakieś zwierzątka rozczulające, albo coś, co dotyczy Polaków. Prawdziwe procesy polityczne, społeczne, ekonomiczne - tego nie ma. My widzimy, bo bardzo precyzyjnie co do minuty bada się oglądalność, że jeśli w programie pojawia się tematyka międzynarodowa, to ludzi w ciągu 30 sekund od oglądania tego programu potrafi odejść pół miliona czy 700 tys. ludzi. Czyli dyktatura kretyna, który nie chce się dowiedzieć, co tak naprawdę się dzieje na świecie, jest tak silna, że trzeba natychmiast dać mu pieska z kotkiem, bo inaczej oni nas zdradzą. Podsumowując: mamy moim zdaniem do czynienia z bardzo kryzysową sytuacją, która polega na tym, że jakakolwiek wartość jest wypychana przez antywartości. Jeżeli zakładamy, że media, takie jak telewizja, Internet, radio - one mają wpływ na postawy ludzkie i na to, co większość Polaków myśli o świecie, jak postępuje i jakie decyzje podejmuje, to jesteśmy w bardzo trudnym i krytycznym momencie dziejów. 


\section{Dyskusja po referacie redaktora Jarosława Gugaty}

Jacek Dąbała: A kto stoi za taką sytuacją?

Jarosław Gugała: Dziennikarstwu zagraża dwugłowy smok. Jedną z głów tego smoka jest polityka, a drugą komercja. Jeżeli nie znajdziemy środków na powstrzymanie tego smoka, to za każdym razem media i wartości, które powinny nieść, będą albo zniekształcane, albo pożerane przez jedną lub przez drugą głowę.

Jacek Dąbała: To jest do zatrzymania?

Jarosław Gugała: Tak. Po pierwsze poprzez stworzenie mediów publicznych z prawdziwego zdarzenia, których zadaniem będzie ochrona pewnych wartości, które uznamy, że warto chronić. Jeżeli dążenie do obiektywizmu jest wartością, to chrońmy to. Jeżeli zapewnienie pełnej palety, pełnego spektrum, punktów widzenia i poglądów politycznych jest pewną wartością, to spełnijmy to. Niech występuje w telewizji publicznej Tomasz Lis i niech występuje jakiś prawicowy publicysta. A niech nie będzie tak, że występuje albo ten, albo ten.

Filip Bajon: Ja bym powiedział coś optymistycznego. Bo na naszych oczach, przed chwilą odegrał się pewien spektakl w mass mediach (czyli w tejże aksjologii, o której mówimy), w których gdyby mi ktoś powiedział, że to się zdarzy, to nigdy bym nie uwierzył. Przykładem jest film „Roma”, który to film jest zrobiony zupełnie inaczej niż wszystkie filmy robione w tej chwili w komercyjnym świecie filmowym. W normalnych warunkach ten film na świecie miałby 20 tys. widzów. Robiony jest bardzo długimi ujęciami, w bardzo szerokich planach, opowiada historię Meksyku, ale to trzeba znać historię Meksyku, żeby wiedzieć, co się ogląda, bo nie ma żadnego offu. Opowiada o dwóch służących z Gwatemali, pozbawiony jest generalnie fabuły i tak naprawdę nie dowiesz się nigdy, dlaczego rodzice reżysera się rozwiedli, bo nie jest to przedmiotem opowieści. Ponieważ jednak film został zrobiony przez platformę cyfrową Netflix, zostały wyłożone na reklamę tego filmu takie pieniądze, że ten film dostał trzy Oscary i miał nominacje dla najważniejszego Oscara jako najlepszy film oscarowy. Jest kupiony przez wszystkie telewizje świata i pokazywany przy pełnych widowniach, i to jest to zjawisko pozytywne, że można. A dlaczego można? Bo Netflix stara się ustabilizować na rynku i chce tym całym rynkiem zawładnąć, więc pokazał, że trudny film artystyczny też może być przedmiotem komercji. I to jest to zjawisko, w które bym jeszcze chętnie uwierzył.

Michał Drożdż: To znaczy, że pieniądze znowu coś wygenerowały. Czyli efekt komercyjny - za pieniądze można również promować wartości. I to trzeba powiedzieć, bo bez tego w dzisiejszym świecie tego się nie da zrobić. 
Jacek Dąbała: Czy ja dobrze rozumiem? Czy w tym kontekście, o którym mówił red. Gugała, czyli zainwestowanie przez media w sposób komercyjny, i Bajon o tym mówi, w tego typu myślenie, odwróciło by tę tendencję, panie redaktorze?

Jarosław Gugała: Na pewno by odwróciło. Jeżeli przy pomocy manipulacji można przekonać Brytyjczyków, żeby wyjść z Unii Europejskiej albo Amerykanów, żeby wybrali taką postać jak Donald Trump na swojego prezydenta, to wszystko jest możliwe. Właśnie tutaj rozmawialiśmy o tych pełnych wartościach i antywartościach...

Nie dopowiedziałem jednej rzeczy - przerażające w tym wszystkim to, że myśmy się do takiego stopnia przyzwyczaili i uznali, że to tak jest i że nic z tym nie można zrobić. Że przejęliśmy metodologię i sposób przedstawiania rzeczywistości form zajmujących się zarządzaniem kryzysowym. I my, media, to zrobiliśmy. Bo, okazuje się, że jeżeli jesteśmy w sytuacji takiej, oglądamy film „House of cards", też Netflix, facet zabija człowieka i tak zachachmęca tą całą sytuacją, że wychodzi z tego czysto, zdobywa prezydenturę USA. W ogóle nie ma w tym wszystkim żadnego problemu - mało tego, jest na tyle urokliwym człowiekiem i aktorem, że wszyscy patrząc na niego (widząc, że jest osobą złą, no kobiety go kochają, mężczyźni go podziwiają), uważają, że jest wzorem absolutnym. I czego nas uczy? Że bez względu na to, jaka jest rzeczywistość, to możemy, powtarzając np. kłamstwa albo stosując odpowiednie techniki, obronić daną wartość. To się bierze z firm komercyjnych, które doradzają firmom przeżywającym jakieś problemy i one doradzają w taki sposób, że nie odwołują się do rzeczywistości, tyko do wrażeń wytworzonych. I tak potrafią zachachmęcić, zawirować opinią, że ratują te firmy - za to się płaci bardzo dużo pieniądze. To wszystko przeniknęło również u nas, najpierw do polityki. W tej chwili ci, co mają lepsza firmę doradczą tego typu, zarządzającą kryzysem, są lepsi, ponieważ ludzie nie są w swojej masie na tyle wyedukowani, są odbiorcą naiwnym, żeby wiedzieć, że mają do czynienia z manipulacją, że ktoś ich po prostu oszukuje. Że uczestniczą w mowie nienawiści, że są wciągani w pewne zjawiska, które są antywartością.

Wojciech Kajtoch: Przepraszam, ale kiedyś to się nazywało faszyzm. Przekonanie, że wszystko można.

Jarosław Gugała: Nie tylko faszyzm, bo każda ideologia totalitarna posługiwała się tego rodzaju postulatami.

Michał Drożdż: Jesteśmy świadkami bardzo niepokojącego zjawiska, które często jest nadużywane i przez polityków, którzy mówią, że wierzymy w mądrość 
narodu, jednocześnie mając świadomości, że tak was zmanipulujemy, jak chcemy. Druga rzecz - media się dostosowują do oczekiwań i potrzeb odbiorców, chociażby te badania informacji zagranicznych, no i teraz pytanie, jakie jest audytorium naprawdę, o jaką grupę my walczymy.

Jarosław Gugała: I takie, i takie. Moja odpowiedź, panie profesorze, na to jest taka, że to jest tak, jak z dziennikarstwem. Nie ma dziennikarstwa obiektywnego, ale jest dziennikarstwo starające się lub odrzucające antywartości. I dziennikarza nie można skazać za to, że on popełnił błąd, że napisał nieprawdę, jeśli on udowodni, że starał się wszelkimi sposobami dotrzeć do prawdy, ale akurat na swojej drodze napotkał na takie argumenty, które kazały mu wyciągnąć taki czy inny wniosek. Nie możemy go za to winić, że dokonując wszystkiego, co powinien dokonać, starając się, doszedł do fałszu, że coś zmanipulował, że podał nieprawdę, że kogoś skrzywdził. Natomiast jeżeli udowodnimy mu, że wiedząc, że było tak i tak, przedstawił z tego wnioski fałszywe, które uderzały potem w kogoś, które były potem mową nienawiści, kogoś oczerniały, to wtedy możemy go skazać.

Czyli nie ma dziennikarstwa obiektywnego, bo nie może być, bo każdy z nas jest jakoś tam ukształtowany przez rzeczywistość, ale podstawową wartością w tym świecie powinno być dążenie do poznania, dążenie do tzw. prawdy i przedstawianie jej przy pomocy realnych przesłanek i argumentów.

Michał Drożdż: Ja się zgadzam, tak być powinno. Chciałem tylko zwrócić uwagę na to, o jaki procent społeczeństwa informacyjnie i publicystycznie my walczymy? Z tych analiz nawet intuicyjnie to jest od 10-20\%. Konsumują rozrywkę, sport... Polskie kanały informacyjne - udział w rynku tych trzech kanałów informacyjnych to jest w granicach całości oglądalności około 12-15\%. TVP Info, TVN 24 i Polsat News

Małgorzata Lisowska-Magdziarz: Relacja 10, 20, 70, która znana jest z badań różnych zbiorowych procesów komunikacyjnych, polega generalnie na tym, że jest 10\% innowatorów, gatekeeperów i liderów opinii, czyli ludzi, którzy mówią innym ludziom bardzo wcześnie, co jest prawdą, co należy myśleć; $20 \%$ takich, którzy się aktywnie przyłączają, aktywnie procesują nowe informacje; 70\% tych, którzy na końcu dadzą się przekonać. W związku z tym problem zapewnienia jako takiego ładu aksjologicznego jest problemem skutecznego komunikowania się z 30\%.

Jarosław Gugała: Miałem kiedyś taką ideę, taki kibuc dla tych wszystkich pozwalnianych z mediów, którzy byli za mądrzy i przez to nikt ich nie chciał 
czytać, byli za drodzy, pisali o rzeczach niszowych. No, słuchajcie - skrzyknijmy się i zróbmy taki kibuc. Będziemy sami płacić za to i będziemy tam publikować bezkompromisowe teksty pod względem długości, głębokości analizy. No, ale jaki masz biznes plan? Jest taki, że może się z czasem pojawią ludzie, którzy będą tego do czegoś potrzebowali i być może powstanie grupa ludzi, którzy być może będą tego na co dzień używać do czegoś, a jak to powstanie, to może powstać tzw. zdrowy snobizm, który będzie powodował, że nawet kretyn będzie musiał przynajmniej udawać, że się o to otarł. A jak już to powstanie, to można do tego przyczepiać reklamy, inne rzeczy robić itd. Przystąpiliśmy do badań, na jaką publiczność w Polsce moglibyśmy liczyć i wyszło na to, że byłoby to maksymalnie 200 tys.

Anna Gemra: Chciałabym nawiązać do kwestii reakcji odbiorców na poniżanie uczestników na przykład programu telewizyjnego. Padło tutaj stwierdzenie, że publiczność lubi brać udział w tym poniżaniu, lubi patrzeć, jak się kogoś poniża. Nie neguję tego, ale mam jedną wątpliwość: czy takie podejście do innych ludzi jest jeszcze w ogóle uważane za poniżanie? Wątpliwość moja wynika z tego, że sądzę, iż publiczne poniżanie, w różnych mediach, stało się praktycznie normą, przestało się więc negatywnie wyróżniać. Z dawniejszych czasów pamiętam program Najsłabsze ogniwo, na licencji brytyjskiej. U nas popularność tego teleturnieju nie była duża i wyprodukowano tylko 4 serie w latach 2004-2006. Jedną z przyczyn małej popularności była podobno, według przeprowadzonych badań, formuła programu. Polegała ona na poniżaniu osób, które brały w nim udział, wywyższaniu się przez prowadzącą, Kazimierę Szczukę, która mając gotowe odpowiedzi udowadniała, że uczestnicy teleturnieju są głupi, niekompetentni, bo tych odpowiedzi nie mają „,w głowie”. Wtedy taka formuła nie uzyskała wystarczającej akceptacji, ale teraz chyba program by się „przyjął”.

\section{Wojciech Kajtoch, Rosjanin godny swych przodków. Semiotyka okładek fanta- stycznych powieści rosyjskich o tzw. „popadańcach”}

Chcę mówić o tym, że my tutaj narzekamy na kryzys wartości, a mamy sąsiadów, którzy w określone wartości wierzą. Dosyć są to wartości proste, są gotowi, żeby je wcielać w życie. Działa tam takie wydawnictwo LitRes, sprzedaje głównie za pomocą e-booków literaturę popularną, przede wszystkim fantastykę i sądzę, 
że jednocześnie mają tak z 2-3 tys. książek na rynku (a może i więcej). I to wielkie audytorium czytelnicze od kilkunastu lat uczy się historii.

Zjawisko jest masowe. LitRes to jedna z najsilniejszych machin propagandowych, jakie widziałem. Nie wiem, jakie tu są nakłady książek papierowych, ale jeśli chodzi o sprzedaż realną, to może być liczona pewnie w milionach egz., bo to jest wielkie przedsiębiorstwo, gdzie płaci się za pomocą kart kredytowych, gdzie są linie pomocy, siedzą konsultanci i załatwiają sprawy rachunkowe, a czasami jest dosyć trudno to kupić, bo działa paręnaście systemów płatniczych. Książka kosztuje (przeliczając ruble na złotówki) około 10-20 złotych.

Rosjanie mieli to do siebie, że w czasach silnego Związku Radzieckiego historią interesowali się w sposób minimalny, bo nie był to temat zbyt bezpieczny. Jednak gdzieś od momentu pierestrojki zaczęły być tam popularne powieści historyczne.

W tej chwili uczą się tej historii w sposób bardzo energiczny, przede wszystkim za pomocą powieści - o dziwo - fantastycznych. Fabuły zawierają taki motyw, że oto współczesny Rosjanin nagle zostaje przeniesiony w przeszłość. To, co mu się tam podoba, a co nie podoba, jak sobie radzi - świadczy z reguły o jego stosunku do współczesności. Ten schemat fabularny i realizujące go fabuły stanowią takie „z niezbyt prawego łoża” potomstwo braci Strugackich, którzy pierwsi na szerszą skalę używali tego rodzaju chwytu, z tym że chodziło im o coś całkiem innego.

Owi „popadańcy” (no i ich twórcy) są to przy tym ludzie, którzy myślą trochę inaczej niż my i jest to bardzo wyraźne - również pod względem aksjologicznym. No, powiedzmy sobie - etos rycerski...

Jest taki typ okładek przedstawiający sceny walk z historycznymi wrogami Rosji prowadzonych przez przeniesionych w daleką lub bliższą przeszłość współczesnych (czy dwudziestowiecznych) Rosjan. Rzecz jasna „przenoszą się” wraz z wyposażeniem. W rezultacie skutki dla wrogów są opłakane, zwłaszcza jeśli współczesny spadochroniarz z bronią maszynową atakuje angielskiego żołnierza z 19 wieku [1]. Inny przykład - człowiek w zbroi z pistoletu maszynowego broni koczowników na Syberii [2].

I ten najdrastyczniejszy - rozstrzeliwanie średniowiecznej konnicy z karabinu maszynowego [3]

Zważcie państwo, że to nie androidy-Terminatory. Realistyczni bohaterowie przenieśli się w przeszłość ze swoimi zabawkami i ich używają, nie bacząc na skutki. Podróż w czasie kończy się realną walką. Prezentowane obrazy pochwalają 


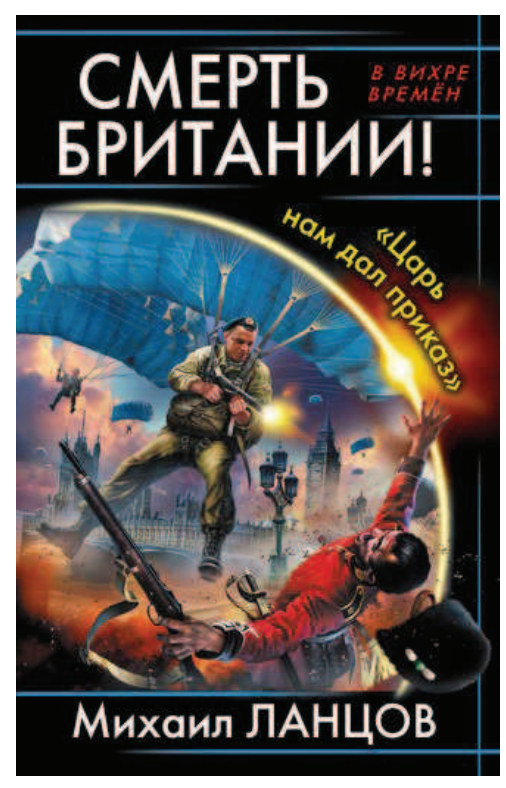

[1]

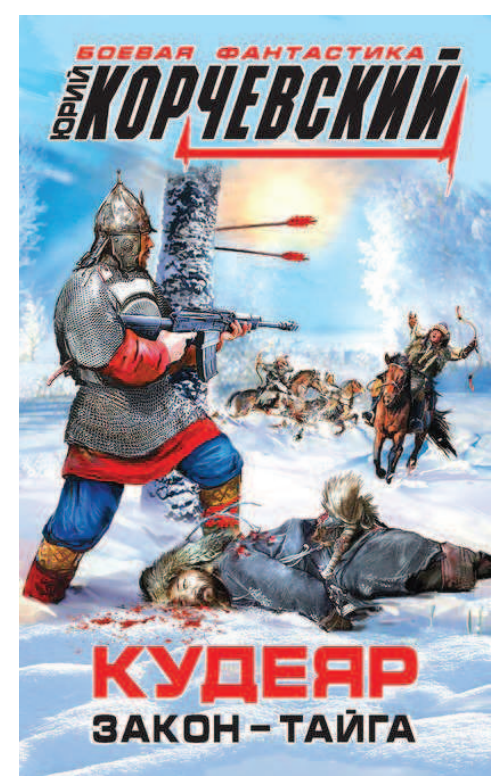

[2]

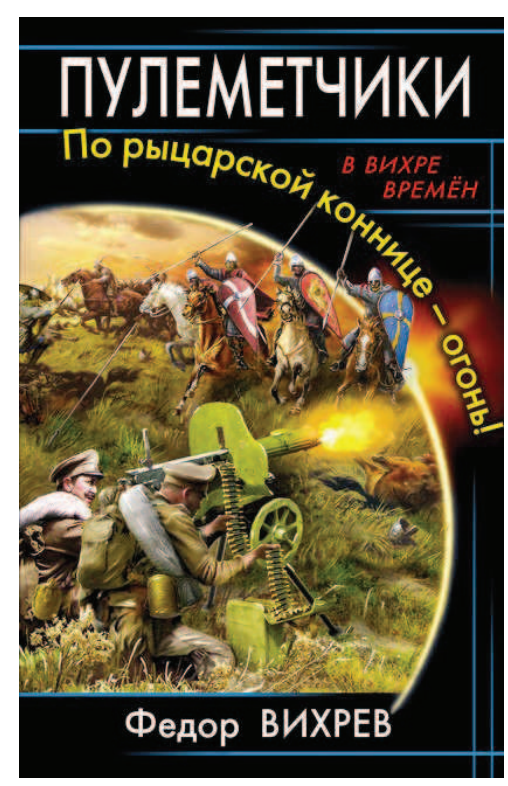

[3]

działanie siłą - nieograniczoną, niezamaskowaną. Czy według wymogów etosu rycerskiego ta sytuacja byłaby akceptowalna? Twierdzę, że u nas by się wstydzono taką okładkę stworzyć.

Kolejne pytanie: czego szuka współczesny człowiek w przeszłości? W przeszłości można też działać pokojowo, to jest chwyt znany z „Jankesa na dworze króla Artura”: człowiek nowoczesny, dysponujący wiedzą „urządza się” w przeszłości. W omawianym przypadku - „poprawia” dzieje imperium. Niekiedy niezbyt etycznie. Zwróćcie Państwo uwagę, jaka chytrą ma twarz ten współczesny biznesmen, który zakłada korporację w warunkach starej Rosji [4].

Zdarzają się też motywy czysto przygodowe. Kolejna okładka przedstawia dwóch współczesnych lotników rosyjskich, którzy zostali strąceni i tajemniczą metodą przenieśli się do 17-wiecznej kolonii i przeżywają rozkoszne sytuacje, wykorzystując e-booki i inne tego typu urządzenia do bawienia młodych dam [5].

Należy zwrócić uwagę, że sytuacja jest zmienna. Motywy pełne agresji wypierają te bardziej rozrywkowe lub refleksyjne. Na pierwszej okładce książki (sprzed 10 lat) nowoczesny samolot ląduje w czasach średniowiecza, takiego rycerskiego, nabożnego, i wywołuje strach i zdziwienie [6]. Na innej okładce pokazana jest grupa nastawionych agresywnie ludzi, na których czele kroczy rycerz we współczesnym niemieckim mundurze, prowadzi ich do walki [7]. Można powiedzieć, że w ciągu tych lat nastąpił spory „postęp”. 


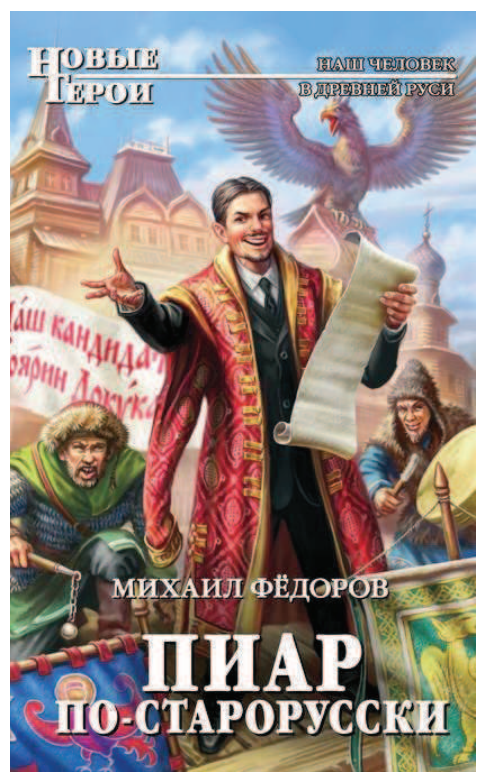

[4]

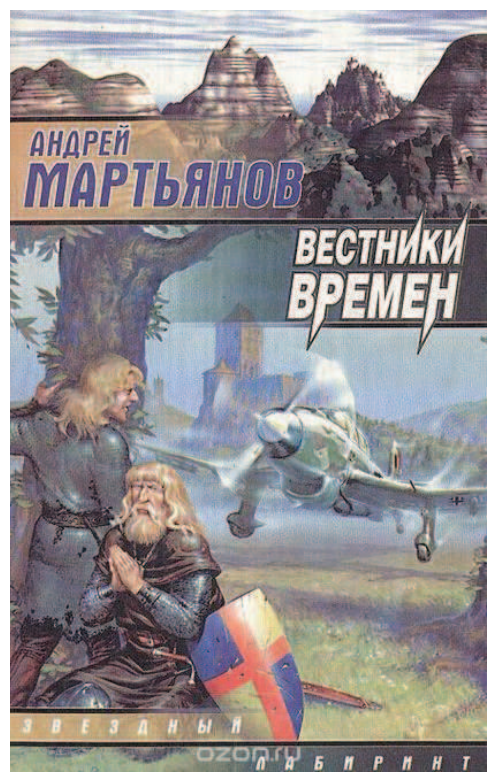

[6]

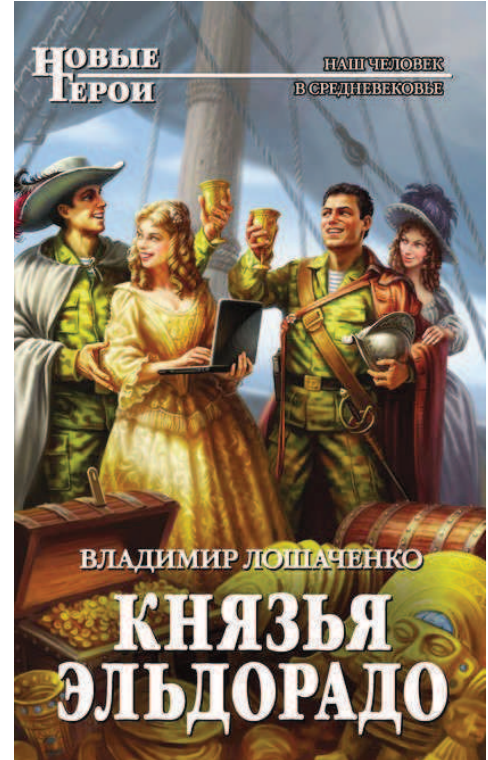

[5]

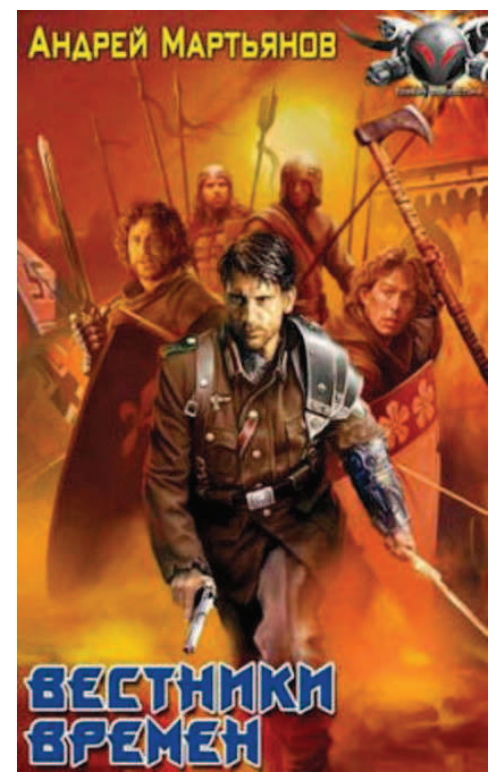

[7]

Jaka myśl przewodnia ukrywa się w tych obrazkach. Moim zdanie one zadają pytanie: Czy my jesteśmy godni naszych przodków? Czy my potrafilibyśmy walczyć tak jak oni? Na licznych okładkach przedstawia się współcześnie odzianego Rosjanina, który został przeniesiony w czas przeszłych wojen i walczy razem ze swoimi przodkami - na przykład podczas II wojny światowej, jak na obrazkach, 


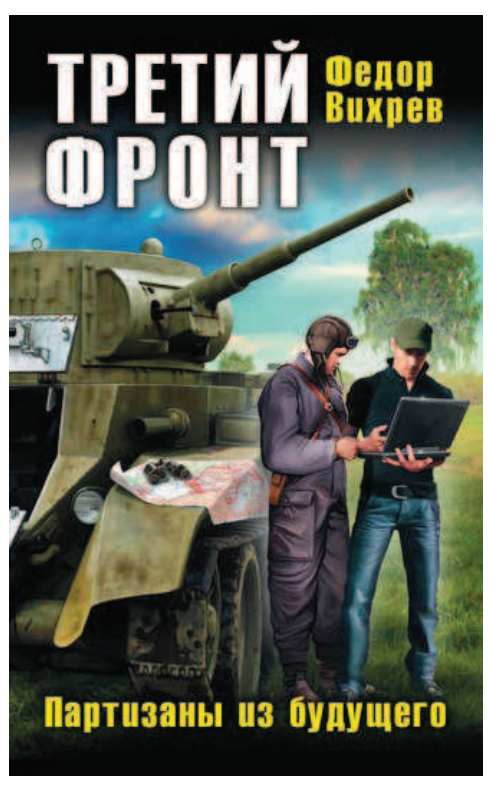

[8]

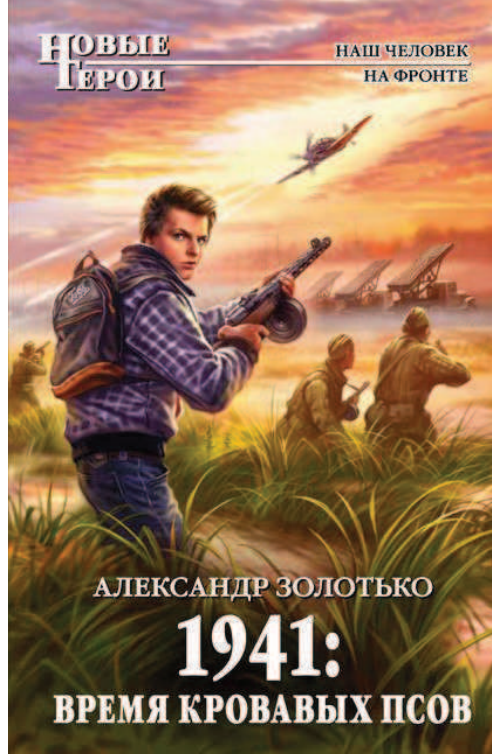

[9]

które przekazuje myśl: na dawnych frontach bylibyśmy sobie równi, moglibyśmy się porozumieć, ja ze swoim ze swoim laptopem mógłbym być tak samo użyteczny jak czołgista [8], mógłbym doradzać, a inny bohater mógłby walczyć jak zwykli żołnierze [9].

Ten motyw występuje też w odsłonie dziecinnej: przykładowo na oko 12-13 letni chłopcy dzisiejsi i dawni walczą w partyzantce [10]. Jest do pomyślenia wersja młodzieżowa, w stylu thrash: Taki współczesny metalowiec (koszulce ma nazwę zespołu Slayer) i świetnie sobie radziłby w czołgu [11], i jako funkcjonariusz SMIERSZ [12]. Obecnie - jak widać - takie budzące grozę stalinowskie instytucje, na ogół krytykowane w rosyjskiej kulturze popularnej lat 90, są teraz inaczej (lub: także inaczej?), przedstawiane - jak bohaterowie, których też należy uznać.

Sądzę, że obserwujemy jeden z przejawów nowej, zaznaczającej się tendencji ideowej: poszukiwania przykładów narodowej, czy raczej państwowej, ideowej zgody. Na przykład na okładce, przedstawiającej uczestnictwo przedstawiciela Rosjan współczesnych w porewolucyjnej wojnie domowej: Przesłanie brzmi: „Jesteśmy razem - ja i moi przodkowie. Ja stoję z piękną dziewczyną (bo jest odziana w strój ówczesnej kozaczki) wokół mnie biali oficerowie z bronią w ręku, trzymam pistolet" [13]. Co to oznacza? - włączenie w starszą tradycję. Dla czytelnika takich utworów nie ma już problemu czy czerwoni mieli rację czy biali. I jedni, i drudzy byli „nasi”. Liczne są przykłady pełnego dowartościowania żołnierzy 


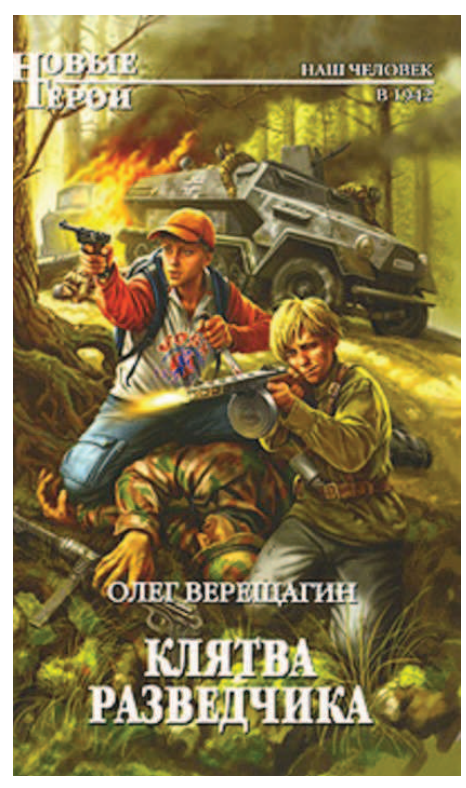

[10]

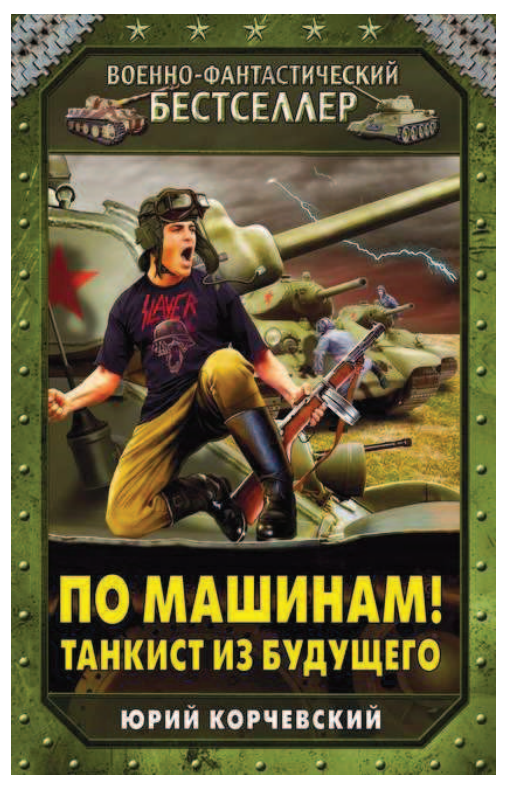

[11]

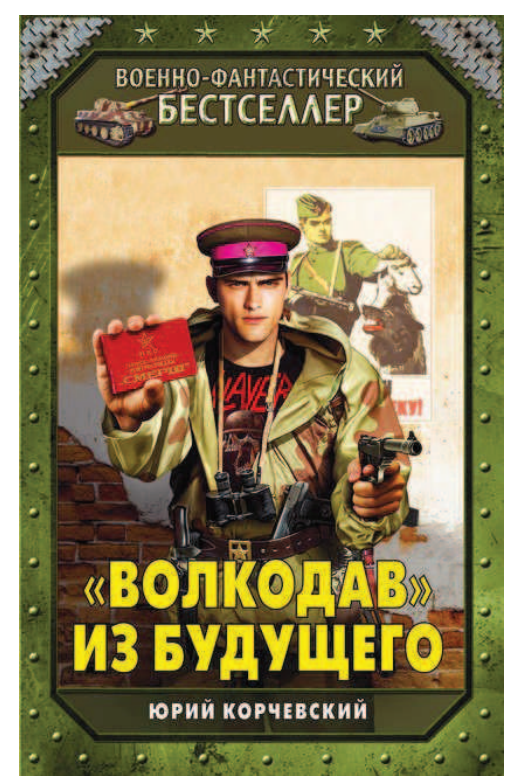

[12]

rosyjskich z lat I wojny i w ogóle carskiego imperium z przełomu XIX i XX wieku. Poszukiwanie zgody może objąć też czasy współczesne, np. przeniesienie w przeszłość może stworzyć sytuację, kiedy nawet Rosjanin i Czeczen muszą współdziałać [14].

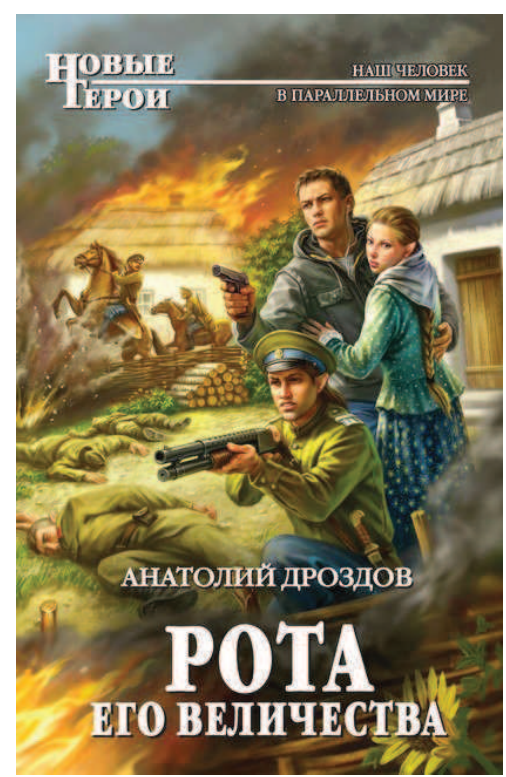

[13]

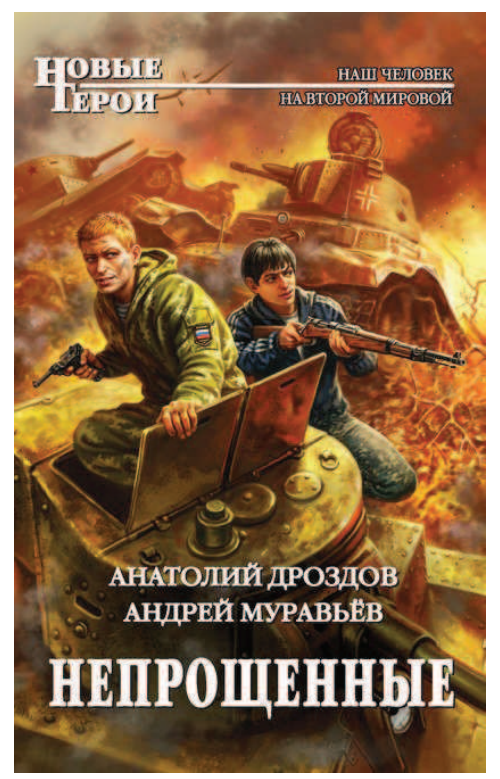

[14]

KULTURA - MEDIA - TEOLOGIA 44/2021 


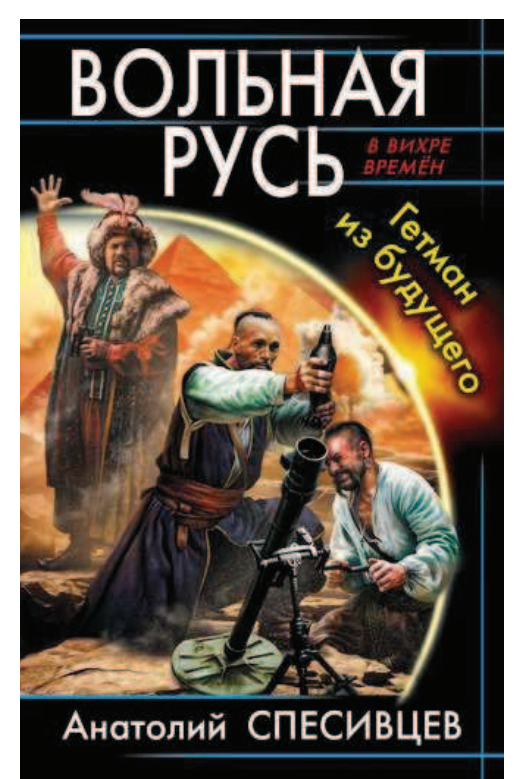

[15]

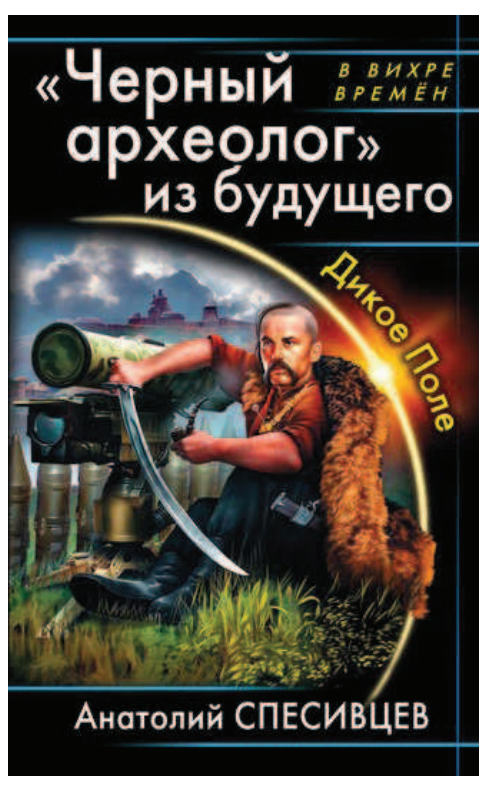

[16]

Ponadto wędrówki w czasie mogą naprawić historyczne krzywdy - np. rozprawić się z tą złowrogą Rzeczpospolitą, lub przynajmniej pomóc XVII wiecznym Kozakom w walce [15. 16]:

Inną charakterystyczną cechą tej literatury - i ilustrujących ją obrazów - jest nawiązywanie do wydarzeń aktualnych. Często na przykład pokazuje się walki $\mathrm{z}$ banderowcami. W tej literaturze panuje zasada, że wszystkie współczesne konflikty, w których bierze udział Rosja. są tam odzwierciedlone.

Np. niedawno Federacja wysłała eskadrę do Syrii i niedługo później ta eskadra przeniesiona $\mathrm{w}$ przeszłość $\mathrm{w}$ cyklu powieści bierze udział w wojnie krymskiej. I oczywiście odwraca zupełnie jej losy. Albo: trwają walki na Ukrainie, poległy pod Debalcewem (luty 2015) rosyjski czołgista przenosi się w czasie, w lata czterdzieste XX wieku, wstępuje w ciało innego czołgisty i zwalcza Niemców.

Jaki jest zatem morał wynikające $\mathrm{z}$ mitów narodowej zgody i przenosin współczesnych żołnierzy na pola dawnych bitew - chyba ten, że w tej literaturze stawia się przede wszystkim na rosyjskich żołnierzy. Wszystko jedno, po której stronie walczyli w domowych wojnach - zawsze byli rosyjskimi żołnierzami. I duchy dzisiaj zabitych przez tych „banderowców, ukrów” czy gdzieś zatłuczonych w Czeczenii, czy na Krymie bohaterów wędrują po historii, wcielając się w ciała żołnierzy i władców zeszłych epok. I bardzo dobrze sobie radzą. 
Szanowni Państwo, moim zdaniem, za pomocą takiej literatury Rosjanie mentalnie przygotowują się do wojny. Szukają jedności, a my się kłócimy. Pytanie - kto byłby lepszy na polu walki?

\section{Dyskusja po referacie prof. Wojciecha Kajtocha}

Jarosław Gugała: Kiedyś prof. Bieńkowski tłumaczył to, co pan na końcu powiedział. Mianowicie, że polski patriotyzm ukształtował się poprzez naszą historię, ponieważ nasze państwo było obce przez wiele lat lub też reprezentowało bardzo wąską grupę kilku procent społeczeństwa. W związku z tym w Polsce patriotyzm zawsze polegał na buntowaniu się przeciwko władzy. A w Rosji czy w Niemczech patriotyzm polegał na wspieraniu własnego państwa, własnego cara, własnego pierwszego sekretarza. Dlatego to jest diametralnie różna historiozofia, różne rozumienie powinności obywatelskich.

Wojciech Kajtoch: Pokażę jeszcze cztery rysunki: Oto pozytywna wartość rosyjska. Ten wielki dowódca [17] jest jakby upozowany na ikonę - oczywiście w tym wypadku w jego ciele jest współczesny Rosjanin. Współcześni Rosjanin może być także marszałkiem ZSRR [19] - proszę także zwrócić uwagę, że postalinowskie lata ZSRR są takim okresem bardzo jasnym. Zawsze jest tam lato, panuje wesoła kolorystyka, na ulicach ciągłe święto [20]. A dla kontrastu: oto

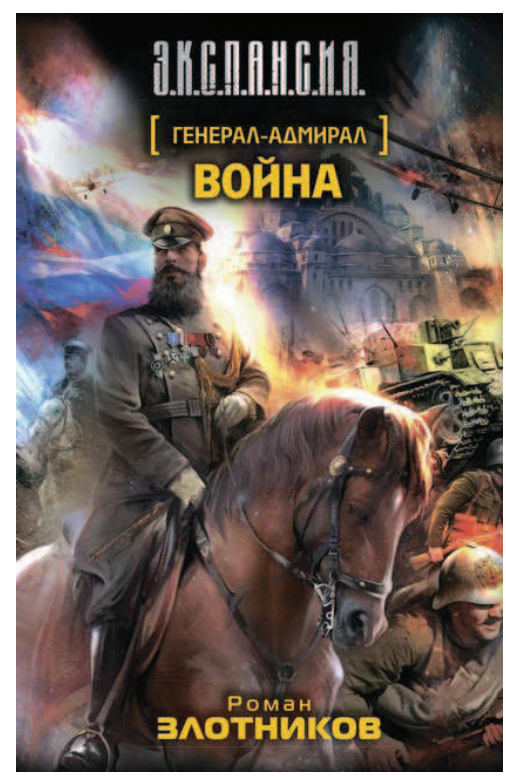

[17]

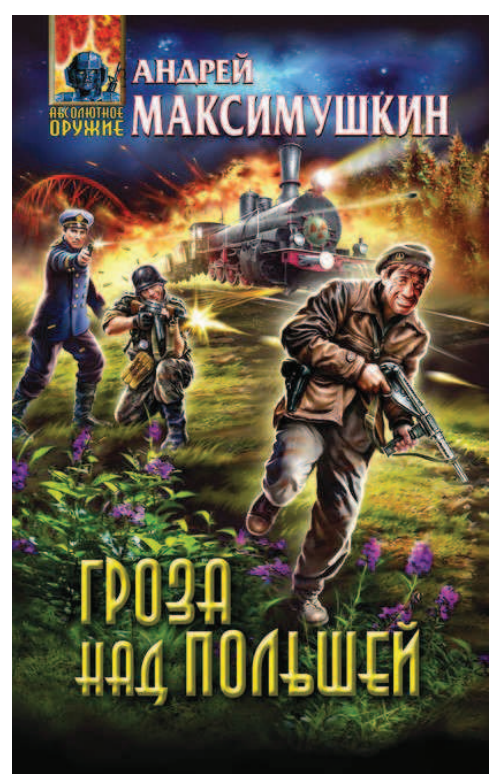

[18]

KULTURA - MEDIA - TEOLOGIA 44/2021 


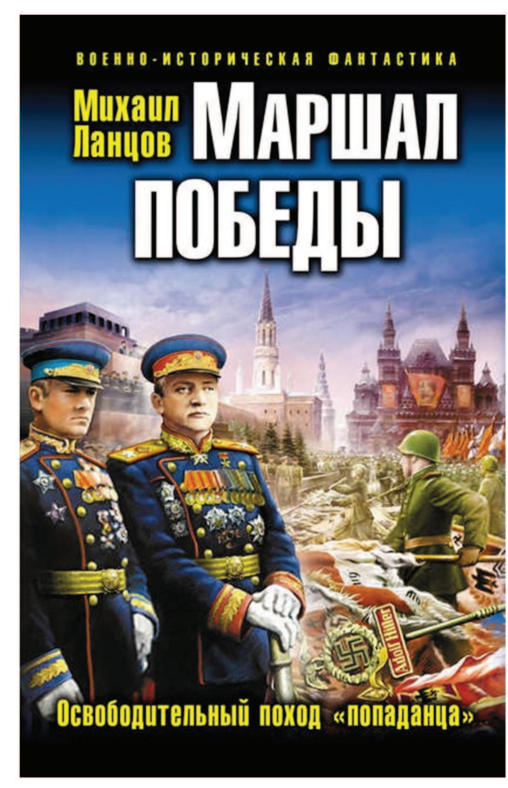

[19]

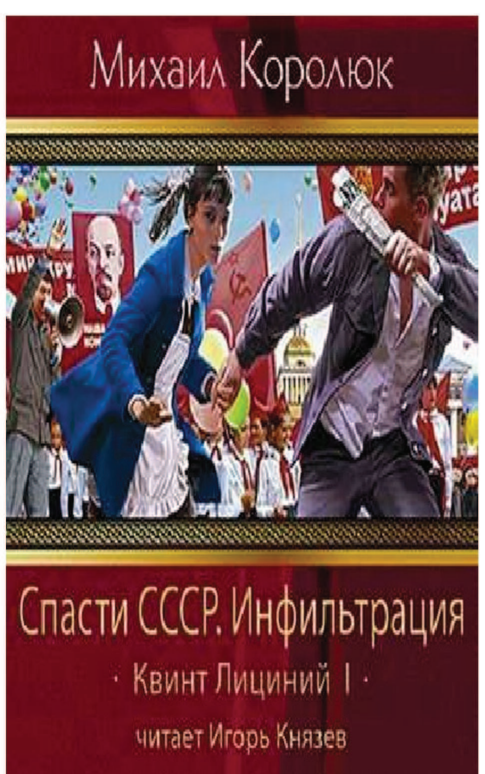

[20]

Polak - AK-owiec. Jak dziarsko on ucieka z wyrazem bezczelności na twarzy. To nie jest ikona. To jest taki mały spryciarz, taki zajczik [18].

Anna Gemra: Czy to, co oni robią w przeszłości albo w przyszłości, ma konsekwencje dla teraźniejszości?

Wojciech Kajtoch: Na razie tylko ogólnie orientuję się w problematyce, ale z tego, co wiem, to przy rysowaniu historii alternatywnej panuje zasada, że ona musi przestać trwać, bo przecież żyjemy w innej historii, niż ta, która wniknęłaby $\mathrm{z}$ tej alternatywnej. I zawsze tworzy taki bąbel w czasie.

Jeżeli papadaniec wraca w czas II wojny światowej to np. ratuje załogę twierdzy brzeskiej. Potem razem biją przeciwnika i wiele innych zwycięstw będzie na ich koncie, niemniej ta historia się nie kończy jakimś znaczącym wydarzeniem. To z reguły są książki, dopisywane jedna po drugiej, są dosyć silnie sformatowane, nawet mają mniej więcej równą liczbę stron. Rzadko się je kończy w sposób radykalny, bo potem nie dało by się dopisać dalszych części. Wiadomo że bohaterowie wszyscy działają na terenie uzupełniającej fikcji historycznej, czyli tworzą sytuacje, rzeczy mogłyby być, ale nie wiadomo czy były - i zupełnie nie wiadomo czym by się skończyłyby, gdyby zaistniały.

Ponadto nie sądzę, by ktoś się odważył przedstawić współczesność jako rezultat historii zmienionej, budując dla czytelnika sugestię, że ta historia dzisiejsza 


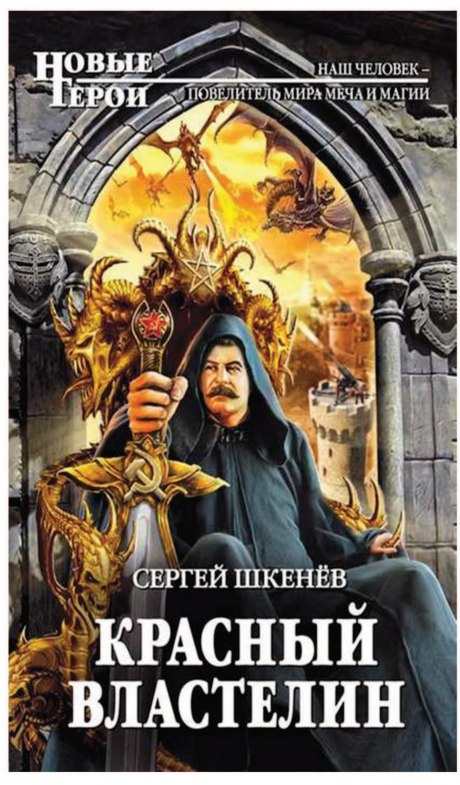

[21]

jest realna. Owszem, istnieją książki w gatunku historii równoległej, są też utopie i antyutopie przyszłościowe, ale wiadomo że to jest fikcja i fantastyka, przy papadańcach niby też to wiadomo, ale im bardziej rzecz jest fikcjonalna i tożsamościowa, to mniejsza z niej korzyść propagandowa.

Na koniec pokażę coś co prawdziwie dziwnego, co jest rezultatem historii równoległej, która jest demonstracyjnie fikcyjna, mieści się w ramach baśni... Stalin jako wódź w świecie gier RPG - tu jest fikcja jawna i nikt tego nie będzie uważał za rzeczywistość. W tym gatunku bohater może popast', czyli znaleźć się w świecie bądź realnym, bądź fantastycznym, bądź przeszłości, bądź w świecie gry. I podejrzewam, że jeżeli Stalin mógł się znaleźć w świecie gry [21], to być może jest taka gra, gdzie jeden z bohaterów jest Stalinem.

Michał Drożdż: Czy okładki są odzwierciedleniem treści?

Wojciech Kajtoch: Z tego, co zdążyłem przeczytać, to nie zawsze. Okładki i noty reklamowe są albo odzwierciedleniem pewnej konwencji, która jest oczekiwana przez czytającego. Konwencje bywają różne - np. jest taka powieść o tym jak oddział współczesnych komandosów nagle trafia do rzeczywistości czerwca 1941 i stawia opór Niemcom. Oddział uczy się walczyć tak jak w grze, w której można na danym levelu paść i gra zaczyna się od początku. Żołnierze bronią mostu, za każdym razem przegrywają, ale też stawiają dłuższy opór. To dobry podręcznik uczący sztuki wojennej. Pisał to profesjonalista, to jest rzecz dla kombatantów, których tam jest takich bardzo wielu, jeżdżą z wojny na wojnę i starają się na tym zarobić, bądź się dowartościować. Tymczasem jej kładka nie odzwierciedla tej konwencji powieściowej - eksponuje inną, tj. walkę samotnego, współczesnego żołnierza z Niemcami.

Seminarium zakończyło wystąpienie, będące jednocześnie i referatem, i podsumowaniem obrad. 


\section{Jacek Dąbała, Audiowizualność a leksykalna hipertrofia}

Pracując przez wiele lat jako praktyk, 20 lat w mediach, i jako badacz mediów, zacząłem szukać pewnego tropu, który pozwalałby z jednej strony oceniać tendencję w granicach dźwięku i obrazu, która się rysuje współcześnie, a zarazem tropu, który pozwalałby tworzyć ten obraz o charakterze komercyjnym.

Wśród państwa wypowiedzi pojawiały się już wątki przerysowań sensacyjnych, pewnej eskalacji przemocy, języka nienawiści itd. To jest jedna strona medalu. I to owszem funkcjonuje, natomiast tak naprawdę brakuje czegoś takiego jak diagnoza, która by pozwalała ujednolicić te mechanizmy i pokazać od strony kompletnie nie branej pod uwagę - mówię to z pełną odpowiedzialnością jako również filolog. To gdzieniegdzie się pojawia, ale mimo że istnieje koncepcja (bo do niej chcę nawiązać, to bardzo ciekawe, bo tu pojawiały się już fenomenologia i Ingarden), to właściwie w zapomnieniu funkcjonuje ta jego, Ingardena, koncepcja jakości estetycznie wartościowych, odmian wartości, takiego myślenia, które bardzo moim zdaniem ukierunkowuje i od strony twórczej, i od strony oceniającej właśnie te współczesne media, głównie audiowizualne.

Ponieważ ta audiowizualność jest czymś jak najbardziej audiowizualnym, właściwie każdy młody człowiek, którego znam, chętnie korzysta z obrazu i dźwięku, postanowiłem się temu przyjrzeć. Proszę zwrócić uwagę na określenie leksykalna hipertrofia, którą ja wywiodłem, kiedy pisałem książkę na temat creative writing; siedem lat mi zajęło badanie tej dramaturgii amerykańskiej. Chciałem odpowiedzieć na pytanie, jakimi kryteriami i środkami się oni posługują, żeby zarabiać tak ogromne pieniądze i zdobywać tak wielkie obszary, czyli właściwie cały świat. I między innymi jednym z elementów, którym się oni posługują, jest coś takiego jak wyjątkowość leksykalno-hipertroficzna. A więc dotycząca języka przede wszystkim i czegoś, czym jest hipertrofia - „zwiększanie się czegokolwiek do nadmiernie wielkich rozmiarów". Czyli hipertrofia, jeśli chodzi o język, ograniczająca się w pewnym momencie do czegoś, co wiąże się z emocjami. A więc rozmawiamy o zdobywaniu rynków, o emocjach i o takim maksymalnym uproszczeniu, ale chcę zaznaczyć, że to, co proponuję, nie wyklucza stosowania również tych chwytów czy środków audiowizualnych na poziomie wysokiej jakości produkcji. To jest podstawowa pomyłka, którą wielu ludzi popełnia moim zdaniem, tworząc dzieła filmowe wybitne bądź niewybitne i medialne. Czyli stawiają pewną cezurę pomiędzy tym, co jest - nazwijmy to takie hipertroficzne - przerysowane, sen-

sacyjne, a tym, co jest jakościowe, wyższe, wysublimowane. To niekoniecznie się 
sprawdza, bo jak państwo przyjrzą się pewnym rozwiązaniom czy to filmowym, czy medialnym, szerzej sieciowym, gdzie audiowizualność dominuje, to zbadawszy to natychmiast zobaczą, że kryteria się powtarzają, natomiast różnice polegają na emocjach. A więc w filmie jakościowo wysokim te wszystkie elementy, o których ja tutaj mówię, czyli m.in. leksykalna hipertrofia, czyli wąziusieńki kanał, one też są, natomiast inaczej to troszkę jest gradowane.

Spójrzmy na to od strony praktycznej - przychodzi ktoś, kto chce wizualnie zarabiać duże pieniądze. Czyli w nowych technologiach, w sieci, odnaleźć się chce, jest naszym studentem, pyta się, co ma robić, żeby go zauważono itd. Najprościej byłoby go zniechęcić, mówiąc: musisz seks i zbrodnie pokazywać, to właściwie będzie wszystko. To by jednak było uproszczenie, o którym mówił redaktor Gugała, takie uchamianie tej rzeczywistości, a nie o to chodzi. Chodzi o to, żeby uświadomić pewne mechanizmy, którymi się możemy posługiwać w pełni świadomie i dzięki temu tę eskalację sensacyjności płytkiej w miarę przynajmniej kontrolować. Żeby to nie był ściek, za przeproszeniem, tylko coś innego.

Kiedy przyjrzałem się temu, co Ingarden proponuje, to on na pierwszym poziomie tych momentów estetycznie wartościowych, mówi o emocjonalności, intelektualności i materiałowości. Ja odrzuciłem te dwie ostatnie kwestie i skupiłem się na emocjach, no bo o tym rozmawiamy.

Świat audiowizualny jest światem emocjonalnym. Przede wszystkim jeśli mówimy w ogóle o zarabianiu pieniędzy. Do tego się w tej chwili odnoszę, czyli do rynku masowego. Proszę zwrócić uwagę, że nawet w naszej rozmowie pojawiły się momenty, że $80 \%$ ludzi tkwi w tej rzeczywistości, a więc oni mnie interesują, ci do zdobycia. Skoro oni reagują przede wszystkim emocjonalnie, bo tu między nami różnic nie ma, to mógłbym z łatwością powiedzieć, że lekceważę ich i odchodzę od nich. Otóż nie, podobnie jak powiedział prof. Bajon, samokwestionujemy tę rzeczywistość, i jak mam się do was dobrać. Tym bardziej że Sieć się do nich dobrała. I wyniki np. Brexitu o tym świadczą. Ponieważ Sieć się do nich dobrała i dobrała się dokładnie stosując to, co wynika z tej koncepcji Ingardenowskiej, zacząłem na to patrzeć od tej strony.

Ingarden, w ramach leksykalnej hipertrofii, mówi o odmianach: doborowości lub taniości, lichości i jakości, sposobach występowania i wymienia tutaj w tych odmianach coś, co w tej leksykalnej hipertrofii, czyli w języku, w nazewnictwie, pozwala nam odbijać się jakby wyobraźnią, imaginacją, ku dźwiękowi i samemu językowi, ku obrazowi. Czyli ktoś kto nie ma nawet wyobraźni audiowizualnej, 
reaguje w sposób emocjonalny na nią, żeby był zrozumiany, no to można się posłużyć czy on sam, tym mechanizmem języka, czyli mechanizmem bardzo podstawowym. Ingarden wymienia takie słowa wśród tych odmian, np. ordynarny, brutalny - ja wybrałem tylko te najbardziej hipertroficzne - żebyśmy tutaj mieli świadomość tej gradacji - mówi: ostry, krzyczący, narzucajacy się, nadzwyczajny, afektowany, patetyczny, nieszczery, podniecający, niepokojacy, obezwładniajacy, wstrząsający, zatrważający.

I proszę wyobrazić sobie teraz, jaką siatką możemy się posłużyć. Ja często pracuję ze studentami i mówię, zrób coś takiego co byłoby interesujące dla mas. Okazuje się, że oni mnie pytają wtedy: „Od czego zacząć?”. No ogół - myślę, że się wszyscy zgodzimy - zaczynamy trochę od wyższych pięter niż język. Nie myślimy o audiowizualności w kategoriach tego odbicia lingwistycznego, tej semantyki, która płynie ze słów, tylko przechodzimy jakby na inny poziom. Myślę, że prof. Bajon wie doskonale, co się dzieje, jak ma takich studentów, no bo jest na innym poziomie, ale nie wszyscy są audiowizualnie uzdolnieni, więc jak im daje ten żer typu słowo, czyli: „Zrób to brutalnie. Zrób mi tę scenę brutalnie. Wyobraź sobie brutalny dźwięk. Wyobraź sobie brutalny język, którym posłużysz się np. w dialogu. Wyobraź sobie brutalny język w komentarzu. Wyobraź sobie brutalny wymiar wizualny". Czyli podejmij wysiłek, kierując się jakby tym, o czym Ingarden mówi i wychodząc ze słowa. „Spróbuj wyobrazić sobie brutalność”. Proszę mi wierzyć, jak robiłem tego rodzaju ćwiczenia, to w cale nie było jasne i proste. Ci młodzi ludzie stawali jak przed ścianą i zastanawiali się, co to znaczy brutalne. Na ogół im się to kojarzyło z jakimiś scenami filmowymi, jakimś napadem, nożem itd. Ja im mówiłem, że mają mi zaproponować jakiś scenariusz, jakiś obraz w miarę spójny, który pokaże właśnie w brutalny sposób tę rzeczywistość. Wielu nie potrafiło wymyślić ścieżki dźwiękowej, która byłaby brutalna, wychodząc od słowa. Brak wyobraźni. Wielu nie potrafiło wymyślić dialogu brutalnego. Co najwyżej obsceniczny, bo im się to myli. Czyli synonimika, bliskoznaczność kłania się od razu. Widać, że pole semantyczne, które tworzy jedno słowo, składające się np. z 20 czy 30 słów, bliskosemantyczne itd., ograniczone jest do np. 5 czy 3 wyrazów. I czasami jest tak, że rozmawiamy i ktoś nas nie rozumie. I to jest dokładnie ten sam wymiar, kiedy przekraczamy to, o czym mówi Ingarden. Więc ja tutaj zaproponowałem tego typu spojrzenie.

Pokażę teraz państwu taki przykład. Wziąłem trzy informacje białe: $\mathrm{z}$ „Wydarzeń” Polsatu, z „Faktów” TVN i z „Wiadomości” TVP. Czyli po prosu te informacje, 
które prezenter czyta tak po prostu czy w studiu do telepromptera. Popatrzyłem sobie na nie, co się wyprawia od tej strony audiowizualnej. Bo wiadomo, widać, jest gadająca głowa, więc utrudnienie, bo siedzi ktoś i mówi, czym dysponujemy w sensie audiowizualnym. Tym słowem, które mówi, mimiką, gestykulacją, no tym wszystkim, co jest w studiu; za wiele tego nie ma. I przyjrzałem się, w jaki sposób odbijają się w sensie hipertroficznym, żeby stworzyć dramaturgię, bo cały czas mówimy o dramaturgii, dziennikarze prezentujący serwisy informacyjne. Np. w „Wydarzeniach” jedna z informacji odpowiadała tym klasyfikacjom jakości estetycznie wartościowych i odmianom Ingardena. Tam się pojawiły takie słowa, które jakby ciągnęły tę dramaturgię i tę narrację audiowizualną. Gdyby tych słów nie było, to wszyscy sobie wyobrażamy: „Dzień dobry, bardzo miło jest w kraju, świeci pogoda i wszyscy śpią". Popatrzyłem sobie czym ciągną w sensie leksykalnym prezenterzy Polsatowscy w tym przypadku i tutaj pojawiły się takie słowa: „nie mieli szans”. Pozwoliłem grupie ludzi odwrócić się, czytałem te słowa i ci, którzy powiedzmy te leksykalną hipertrofię gdzieś sobie wyobrazili, to mieli podnieść rękę. „Nie mieli szans” - wszyscy podnieśli, to ich zainteresowało w informacji białej. „Zginęło” - podnieśli. „W katastrofie” - podnieśli. „Ofiar” - podnieśli. „Siła uderzenia” - podnieśli. Ale tak naprawdę podnosili, pokazuję państwu tę leksykalną hipertrofię, w prawdziwym wymiarze. Przy trzech słowach: „rozerwała”, „na strzępy”, „rozbił się” - tu ta wyobraźnia zadziałała. Ja potem pytałem, co sobie wyobrażają niektórzy, gdy tego typu słowa się pojawiają, czy jest łatwiej. Tak, zdecydowanie, ta wyobraźnia audiowizualna wtedy po prostu pracowała. Przy tych pierwszych, które przeczytałem, pracowała mniej. „Nie mieli szans” jest bez porównania hipertroficznie słabsze od np. „na strzępy”.

I teraz, o co by w tym wszystkim chodziło? 0 to, żebyśmy mieli świadomość, że jak przekazujemy ludziom tę informację czy sztukę, to oni po prostu zaczynają rozumieć inaczej kształtowanie emocji odbiorcy, staje się to mniej przypadkowe. A więc sam język w swojej warstwie pozwala wydobywać pewne napięcia, które mogą się pojawić gdzieś tam dalej.

Konkluzja: odpowiedzialność za uczenie ludzi korzystania z języka, to jest odpowiedzialność za emocje, jakie potem powstają. Prof. Kajtoch pokazywał nam nic innego, tylko emocje. Obraz plus - jakoś tak się dziwnie składa - nie dźwięk, ale język. Język, który sobie ktoś wyobraża, który pozwala mu się imaginować w jakiś dziwnych przetworzeniach, sceneriach, które są infantylne, ale ten infantylizm jest tak potwornie silny, że nie można go nie zauważyć. 
To moim zdaniem staram się robić, trzeba uświadamiać ludziom mediów, twórcom, ale przede wszystkim studentom, młodym ludziom, którzy mało czytają, to już wiemy, że korzystają jednak z języka. Nawet jak esemesują, nawet jak przekazują najszybsze z możliwych informacji, to jednak korzystają z języka. Do czego zmierzam - nie odwracam się plecami do ich braku oczytania, nie gniewam się, że mniej czytają, że inaczej korzystają z tego świata kultury i języka. Tylko szukam dróg, którymi najłatwiej dotrę do nich. I okazuje się, że koncepcja Ingardenowska, tych wszystkich przestrzeni, które on rysuje, jest znakomita. Ona jest tak fascynująca, jakby przewidziała wszystkie odmiany, wszystkie meandry. W zasadzie można z niej wyjąć to, co jest dzisiejszym problemem emocjonalnym mediów, i można przejść na poziom, który jest najwspanialszą jakością po stronie filmu.

Pomyślałem sobie, że trochę odkurzę naszego genialnego fenomenologa i zaproponuję pewną teorię, czyli tę leksykalną hipertrofię w praktyce audiowizualnej. Nie będę przeciążał tutaj państwa mówieniem, bo zarysowałem tylko w sposób uproszczony pewien kierunek mojego rozumowania. Jest to na pewno nowe, inne, zapewne dla niektórych będzie kontrowersyjne, trudne do przyjęcia. No, ale jak państwo zauważyli, mamy tutaj wszyscy swoje zdanie, staramy się go bronić. $\mathrm{Na}$ tym też polega urok analizowania mediów i niekoniecznie musimy trzymać się tak bardzo definicyjnie pewnych ustaleń, szukajmy po prostu nowych dróg. Staram się uzasadnić to, że słowa mogą być audiowizualne i mogą uczyć, że jak zaczynam wyjaśniać audiowizualność to mogę zacząć od słów, a niekoniecznie od obrazów.

Udzielam licencji do eksploatacji praw autorskich do przesłanego utworu na zasadach licencji Creative Commons Uznanie autorstwa - Użycie niekomercyjne Bez utworów zależnych 4.0 Międzynarodowe (CC BY-NC-ND 4.0).

Mateusz Flont - Zakład Ośrodek Badań Prasoznawczych; Instytut Dziennikarstwa, Mediów i Komunikacji Społecznej; Wydział Zarządzania i komunikacji Społecznej; Uniwersytet Jagielloński w Krakowie ORCID: 0000-0003-1509-4815 